Journal of Marine Systems

October 2016, Volume 162, Pages 57-72

http://dx.doi.org/10.1016/i.jmarsys.2016.04.001

http://archimer.ifremer.fr/doc/00326/43725/

(C) 2016 Elsevier B.V. All rights reserved.

\title{
South-Eastern Bay of Biscay eddy-induced anomalies and their effect on chlorophyll distribution
}

\author{
Caballero Ainhoa ${ }^{1,{ }^{*}}$, Rubio Anna ${ }^{1}$, Ruiz Simón ${ }^{2}$, Le Cann Bernard ${ }^{3}$, Testor Pierre ${ }^{4}$, Mader Julien ${ }^{1}$, \\ Hernández Carlos ${ }^{1}$
}

${ }^{1}$ AZTI-Tecnalia, Marine Research Division, Herrera kaia portualdea z/g, 20110 Pasaia, Spain

2 Instituto Mediterraneo de Estudios Avanzados, IMEDEA (CSIC-UIB), Esporles, Spain

${ }^{3}$ Laboratoire de Physique des Océans, UMR 6523 CNRS-Ifremer-IRD-UBO, Brest, France

${ }^{4}$ CNRS, Université Pierre et Marie Curie (Paris 06), UMR 7159, Laboratoire d'Océanographie et de Climatologie: Expérimentations et Approches Numériques (LOCEAN), Paris, France

* Corresponding author : Ainhoa Caballero, email address : acaballero@azti.es

\begin{abstract}
:
The analysis of deep-water glider hydrographic and fluorescence data, together with satellite measurements provides a new insight into eddy-induced anomalies within the South-Eastern Bay of Biscay, during summer. Two cyclonic eddies and a SWODDY have been observed in different glider transects and by means of different sources of satellite data. Vertical profiles reveal complex structures (characteristic of the second baroclinic mode): upward/downward displacement of the seasonal/permanent thermocline in the case of X13 and the opposite thermocline displacements in the case of the cyclones. This is a typical behaviour of mode-water and "cyclonic thinny" eddies. A qualitative analysis of the vertical velocities in the anticyclone indicates that though geostrophy dominates the main water column, depressing the isopycnals, near the sea-surface the eddy-wind interaction affects the vertical currents, favouring Ekman pumping and upwelling. The analysis of the $\Theta-$ $S$ properties corroborates that inside cyclones and between the 26 and 27 isopycnals, net downwelling occurs. These two types of intra-thermocline lenses appear to deeply impact the Chl-a fluorescence profiles, since the maximum Chl-a fluorescence is located just below the seasonal thermocline. The mean Chl-a fluorescence was higher in the anticyclone than within the cyclones and the mean for the entire study period; the highest values were observed in the centre of the anticyclone. These results are in agreement with previous findings concerning the SWODDY F90 and surrounding cyclones, located in the South-Western Bay of Biscay. Significant differences in the $\Theta-S$ properties of the two cyclonic mesoscale structures have been observed: higher temperatures and lower salinity in the easternmost cyclone. Finally, time variation of the salinity content of the shallowest water masses of the anticyclone (salinity decreasing over time), probably indicates advective mixing processes occurred during the mission.
\end{abstract}

Keywords : Eddies, Bay of Biscay, Glider, Hydrography, Mesoscale, Eddywind 


\section{Introduction}

\subsection{Hydrography of the South-Eastern Bay of Biscay}

The geographical area covered in this study is located in the South-Eastern Bay of Biscay (SE-BoB) between the Cantabrian coast and $45^{\circ} \mathrm{N}$ and from $2.5^{\circ} \mathrm{W}$ to $4.5^{\circ} \mathrm{W}$ (Fig. 1). Upper and intermediate water masses of the SE-BoB (from surface to $1000 \mathrm{~m}$ 
depth) are the Eastern North Atlantic Central Water (ENACW) and the Mediterranean Water (MW) (Van Aken, 2000; Lavín et al., 2006). ENACW is originated by winter mixing over a region from North-East of Azores to the European margin, bounded by the North Atlantic and the Azores currents (Pollard and Pu, 1985; Pollard et al., 1996), and it delimits the upper permanent thermocline (Prieto et al., 2013). The core of ENACW has a potential density $\left(\sigma_{\Theta}\right)$ between 27.1 and 27.2 (Somavilla et al., 2009) and is located in the Bay of Biscay at about $350 \mathrm{dbar}$. The bottom of ENACW is characterized by a salinity minimum layer (at about $500 \mathrm{dbar}$ and $\sigma_{\odot}=27.2-27.3$ ). Below the ENACW, the Mediterranean Water (MW) begins to influence the intermediate waters (Somavilla et al., 2009). The core of the MW is mixed with less saline waters along the Cantabrian slope and, consequently, the maximum salinity of MW in the SE-BoB is lower than the values observed in other areas. The mixed layer in this temperate sea describes a seasonal cycle, in tune with the net solar flux. The analysis of two years of hydrographical data concludes that the temperature of the water in the SE-BoB starts to rise from late April, with maximum values $\left(20-22^{\circ} \mathrm{C}\right)$ in July-August, and begins to decrease in October-November (Rubio et al., 2013). During summer, the Mixed Layer Depth (MLD) is located between $30 \mathrm{~m}$ (Somavilla et al., 2011) and 50 m depth (Rubio et al., 2013).

These are the average characteristics of the water masses in the study area, but it should be taken into account that these mean properties are affected by high and low frequency variations. A recent description of the water masses, mean circulation patterns and their variability in the Bay of Biscay is provided by Pingree and GarciaSoto (2014). One source of variability is the seasonal arrival of the salty and warm subtropical waters by the Navidad slope current (Pingree and Le Cann, 1990) in the SE-BoB. Evidences of the variability linked to the slope current in the SE-BoB have been recently addressed by Garcia-Soto and Pingree (2012), Rubio et al. (2013), Esnaola et al. (2013), Pingree and Garcia-Soto (2014) and Solabarrieta et al. (2014). Another process that modifies the hydrography of the SE-BoB is the coastal upwelling, forced by seasonal winds along the Cantabrian coast. Easterly winds induce a transport of colder and fresher waters offshore (Lavin et al., 2006). Usually, from May to September wind patterns favour coastal upwelling, reversing the cyclonic circulation over the near-surface slope (Le Cann and Pingree, 1995). Input of fresh water from the river outflow also induces a hydrographic variability; it occurs from late winter to early spring, significantly modifying the salinity of the surface adjacent shelf. During certain years, depending on the wind regime, this fresh water reaches the shelf break in low salinity lenses (Puillat et al., 2004). The migration of this type of water in 2009 was investigated by Reverdin et al. (2013), concluding that fresh water masses from river outflows (winter-spring) were spread to the shelf break (early May), observing two months after (mid-July) that freshwater spread from west of the Landes Plateau to $4^{\circ} \mathrm{W}$. Internal waves induce high frequency variability, during summer stratification, to the mean hydrographic distribution of the near-surface waters. These waves that may have two possible origin places, the shelf break (Pingree et al., 1986) and the central Bay of Biscay (New and Pingree, 1990; 1992) have amplitudes of up to $50-60 \mathrm{~m}$ periods of $20-$ $30 \mathrm{~min}$. And finally, eddies, which are described in detail in the following Section, generate mesoscale variability on the mean hydrographic conditions of the SE-BoB.

\subsection{Eddies in South-Eastern Bay of Biscay}

In the SE-BoB, Water Oceanic EDDIES (SWODDIES) are seasonally originated from instabilities of the Navidad warm slope current as it encounters topographical irregularities; SWODDY F90, the first SWODDY hydrographically surveyed and captured in a SST image in 11 July 1990 around $45^{\circ} \mathrm{N}$ and $8^{\circ} \mathrm{W}$ (Pingree and Le Cann, 
1992a), was characterized by a homogeneous warm $\left(12.95^{\circ} \mathrm{C}\right)$ and salty $(35.74)$ core centred between 70 and 280 dbar (Pingree and Le Cann, 1992a). Near the centre of SWODDIES the seasonal pycnocline shallows. The vertical structure and its implication on the hydrology and ecology of the surrounding waters during the stratification period, has been investigated in the migrating SWODDY F90 (Garcia-Soto et al., 2002) and in the non-migrating SWODDY-like eddy AE6 (Garcia-Soto et al., 2002; Rodríguez et al., 2003; Fernández et al., 2004; Sánchez and Gil, 2004). The temperature of SWODDY F90's core, ranged from $12.9^{\circ} \mathrm{C}$ to $13.0^{\circ} \mathrm{C}$ and showed a minimum of Brunt-Vaisäla frequency $<0.5 \mathrm{cph}$. The thermocline was domed upwards inside it, where the Chlorophyll-a (Chl-a) concentration peaked. The doming of the thermocline was reflected at the sea surface, as a cooler signal (Garcia-Soto et al., 2002). Anticyclonic eddy AE6, located around $45.5^{\circ} \mathrm{N}$ and $6^{\circ} \mathrm{W}$ was intensively investigated during August 1998. It was observed that its central core was situated between 80 and $200 \mathrm{dbar}$ and that it was warmer $\left(12.6-12.8^{\circ} \mathrm{C}\right)$ and saltier (35.7) than the surrounding water masses. The seasonal pycnocline described an upward doming up to $30 \mathrm{dbar}$, whilst the permanent pycnocline was depressed (Fernández et al., 2004), being a typical behaviour of mode-water eddies (McGillicuddy et al., 1999).

Depth-integrated phytoplankton within AE6 showed a higher concentration than in the surrounding waters (Rodriguez et al., 2003; Fernández et al., 2004); this higher Chl-a concentration was due to the uplifting of the seasonal pycnocline that induced nutrient pump into the photic layer (Pingree and Le Cann, 1992a), but it was also hypothesized that internal waves could inject nutrients into the Deep Chlorophyll Maximum (DCM, Fernández et al., 2004). Eddy induced Ekman pumping has been described as one of the four mechanisms that influence near surface chlorophyll concentration, besides eddy stirring (azimuthal advection around eddies), trapping of particles by nonlinear eddies and upwelling/downwelling mechanism during the intensification phase (Gaube et al., 2014). Cyclones and mode-water eddies tend to upwell nutrients during their formation and intensification phases (McGillicuddy et al., 2007), which results in local phytoplankton blooms. In the case of mode-water eddies, the shallow pycnoclines are upwelled carrying nutrients to the photic layer and favouring the growth of phytoplankton communities. In another area of the North Atlantic Ocean, an experiment that investigated the phytoplankton communities within cyclones and mode-water eddies, concluded that the eddy/wind interactions induced vertical nutrient upwelling in mode-water eddies, whilst diminished it in cyclones (McGillicuddy et al., 2007). In this work, the positive vertical currents, estimated by an eddy/wind interaction model (accounting only for the surface stress arising from wind and ocean velocities differences) in a mode-water eddy were between 0.1 to $1.6 \mathrm{~m} \mathrm{day}^{-1}$. These values were of the order of that measured by a released tracer $\left(0.4 \mathrm{~m}^{2}\right.$ day $^{-1}$, McGillicuddy et al., 2007). Gaube et al. (2015) have recently quantified, from a global population of mesoscale eddies, isolated by means of satellite altimetry, the three mechanisms that induce Ekman pumping in eddies. Their analysis showed that eddy induced Ekman pumping is primarily caused by wind-surface currents interactions (through wind-ocean velocity differences and interaction of surface wind stress with surface ocean current vorticity gradients) while the mechanism related with SST spatial variability in eddies is secondary (excepting areas with strong frontal regions). These three mechanisms are also related with the decay of the observed structures, with a scale of $1.3 \mathrm{yr}$ for typical eddies and conditions (Gaube et al., 2015).

A recent study, where the formation of intrathermocline lenses are modelled by considering eddy-wind interactions, suggests that these structures instead of being generated from a distant origin, are the consequence of the local eddy wind interaction (McGillicuddy, 2015). Thus, beside mode-water eddies, the so-called "cyclonic thinnies" that are characterized by a cyclone with and upward/downward displacement of the 
permanent/seasonal thermocline, are the result of the continuous wind stress that induce upwelling in anticyclones and downwelling over cyclones.

Although once generated they tend to migrate westward, several SWODDIES in the area have been observed to remain quasi-stationary during months near the same position around $44^{\circ} \mathrm{N}-4^{\circ} \mathrm{W}$ (Pingree and Le Cann,1992a, 1992b; Garcia-Soto et al., 2002; Caballero et al.,2008; Caballero et al., 2014). They have been named $4^{\circ} \mathrm{W}$ SWODDIES and accordingly, this terminology is hereinafter adopted in this work. A recent study concludes that between 2003 and 2010 this type of SWODDY is present almost every year from the end of winter-beginning of spring, to the beginning of fall (Caballero et al., 2014). Its position is limited to the East by the Landes Plateau, to the West by Le Danois Bank and Torrelavega canyon and to the North-West by the Jovellanos seamount (Fig. 1). From satellite observations and model simulations, the authors suggest that the origin of this structure in 2008 seems to be linked to a warm water current located around $43^{\circ} 42^{\prime} \mathrm{N}-3^{\circ} 30^{\prime} \mathrm{W}$ in mid-January.

The "Glider campaign to estimate the 3D structure of an Eddy in the South-Eastern Bay of Biscay" (GESEBB) mission took place during summer 2013 in the SE-BoB. It was initially designed to measure the hydrodynamic properties of a quasi-stationary eddy by means of a deep-water glider, supported by satellite oceanography data/images. However, the flexibility of the glider allowed adapting the mission plans (waypoints, maximum depths, sensors configuration...) and sampling other adjacent coherent mesoscale structures, as they were detected from different complementary measuring instruments (mainly, satellite data). The objectives of this study are firstly to analyse, based on new high-resolution $(\sim 3.3 \mathrm{~km})$ in situ measurements and remote sensing information, if the eddies of the study area modify the hydrography and the consequences on the fluorescence distribution, in the water column. This was previously demonstrated for SWODDIES and surrounding cyclones located to the west of our study area (F90) by using a continuous undulating fluorimeter and CTD (SeaSoar) from surface to $350 \mathrm{~m}$ depth (Garcia-Soto et al., 2002) and for the anticyclonic eddy AE6 from satellite chlorophyll data and biological in situ data (GarciaSoto et al.. 2002; Rodríguez et al., 2003; Fernández et al., 2004). Here, we carry out a new analysis, using an unprecedented spatial high-resolution resolution hydrography data in our study area and sampling the water column from surface to $1000 \mathrm{~m}$ depth. A second objective is to infer which physical drivers influence the vertical structure of these eddies.

This paper is structured as follows. First, the GESEBB mission and the data and methods are depicted in Section 2. In the third Section, the main results of the analysis of three different eddies and of the differences in the hydrography and fluorescence of waters outside and inside (anticyclonic or cyclonic) eddies are presented. Finally, the fourth Section is devoted to summarise the study and to review the main conclusions.

\section{Data and methods}

\subsection{GESEBB mission}

GESEBB was an observational mission that comprised the measurements of a deep water glider, Sea Surface Temperature (SST) and Chl-a concentration satellite images and altimetry data in near real time. The objectives of the campaign were to analyse in detail the vertical structure of a $4^{\circ} \mathrm{W}$ SWODDY in a period that is especially interesting regarding the biological cycle of some key species for the fishery activity. The mission took place from 23 July to 24 September 2013. The study area and the glider tracks, 
whose data are used for this study, are shown in Figure 1. The Slocum glider that reached a maximum depth of $1000 \mathrm{~m}$ was equipped with CTD, dissolved oxygen, and fluorescence-turbidity sensors (see details on gliders in Testor et al., 2010). All the sensors were configured at a frequency of $1 / 8 \mathrm{~Hz}$, for measuring during diving and climbing, until the end part of the mission when the battery begins to run down. At this time, to save energy and successfully achieve the planned mission, they were shifted to measure during dives only. The autonomous vehicle transmitted in near real time data during surfacing (every $\sim 4 \mathrm{~h}$ ). High resolution data were retrieved after the glider recovery. Despite there were pre-existing sampling plans, these were modified according to the new information obtained from the glider and from the other available measurements.

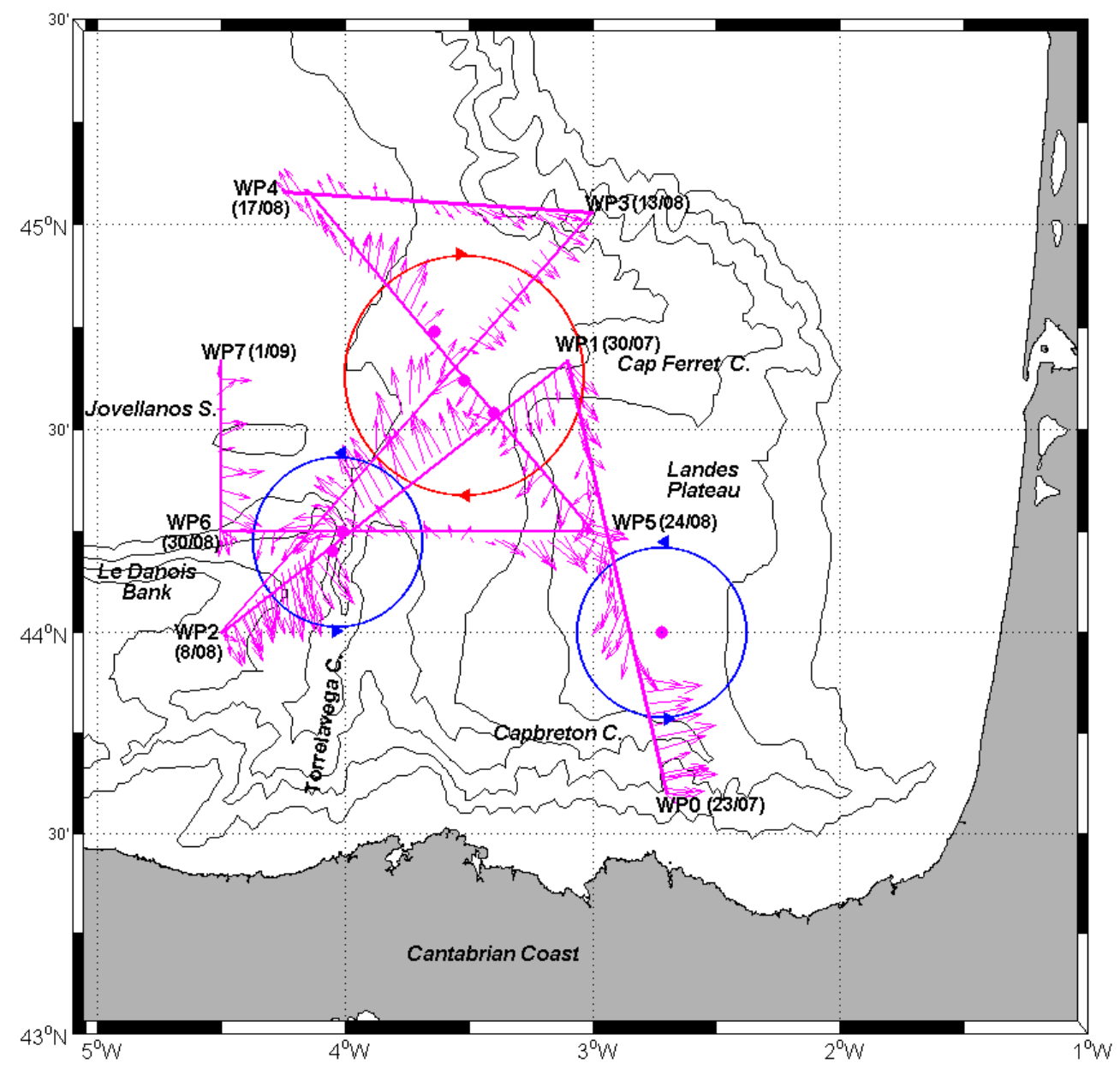

Figure 1: Study area. Pink lines show the tracks followed by the glider from the initial (WP0) to the last (WP7) waypoints considered in this work. Pink vectors and points represent the vertical integrated currents and the centre of eddies, respectively. A sketch of the position and the area occupied by the observed anticyclone (red circle) and cyclones (blue circles). Pink points indicate COEs (Centre Of Eddies) using the method described in Section 2.2. Isobaths (m): 200, 1000, 2000, 3000 and 4000.

*Note: the trajectories of the glider have been smoothed in order to simplify the sketch; the real trajectories can be consulted in the following link:

http://glider83a.dt.insu.cnrs.fr/EGO_groundstation/html/campe/GESEBB/deployment_summary.txt.kml

\subsection{Glider data processing}

Following the EGO/GROOM standards (GROOM group, 2014), the glider compass was properly calibrated before the deployment but the oceanographic sensors (CTD, dissolved oxygen, Chl-a fluorescence, Turbidity) could not be compared with reference 
profiles as recommended due to logistical issues. Sensors were calibrated by the manufacturers before the deployment. For instance, the optical sensor measuring Chla fluorescence was factory-calibrated in the laboratory before the mission. Glider TS data have been processed using standard protocols for Seabird instruments and a more specific correction methodology to avoid errors due to the thermal lag in the unpumped CTD sensors (Garau et al., 2011). To this end, only profiles with complete downcasts and upcasts were selected, since this methodology is based on the minimization of the differences between both casts of the same profile. After data processing, 248 profiles were obtained with a mean $3.3 \mathrm{~km}$ along-track resolution and vertically averaged to $1 \mathrm{dbar}$ intervals. Two different methods have been used in order to distinguish the measurements corresponding to cyclones/anticyclones. First of all, the Centre Of Eddy (COE) finder method, developed by Nencioli et al. (2008), has been applied to the vertically integrated currents. This method allows to estimate the position of the centre of an eddy, by decomposing the velocities into tangential and radial components relative to each point of a defined grid. The COE is assumed as the grid point for which the mean tangential velocity is maximal. Secondly, for estimating the eddy diameter we take into account the typical vertical temperature structure of the anticyclones (i.e. depression of the permanent thermocline), and of the cyclones (i.e. uplift of the permanent thermocline). To objectively set the eddy diameters, we use the $11.5^{\circ} \mathrm{C}$ isotherm depth time series and the doming observed in it, as result of the upliftdownlift induced by the structures. The limits of each eddy have been calculated from the $11.5^{\circ} \mathrm{C}$ isotherm, computing the point where the isotherm depth time series crosses the mean value. The limits obtained using this approach give a good approximation to the eddy diameters, most of the time giving coherent but slightly larger values than those defined by the maximum of integrated orbital velocities. The maximum of integrated orbital velocities criterion could not be used for all the structures/transects, since orbital velocities showed high variability and did not always allow a clear detection of eddy periphery.

The depth of the seasonal thermocline has been computed by adjusting the vertical profiles of the temperature to a logistic function (following the methodology given in Alvera-Azcarate et al., 2008). The inflexion point of the logistic function (easily determined using its first derivative maximum) marks out the mean depth of the most intense gradient vertical bins of the profiles within the thermocline; thus, it provides an approximation to the mean depth of the thermocline. This methodology is compared with three commonly used approaches to estimate the MLD and the depth of the thermocline (Fig. 2). The MLD is approximated through two methods based on fixed thresholds, with a finite difference criterion of temperature from $10 \mathrm{~m} \mathrm{of} 0.2^{\circ} \mathrm{C}$ (de Boyer-Montegut et al., 2004) and $1^{\circ} \mathrm{C}$ (Nencioli et al., 2008). For the depth of the seasonal thermocline, a criteria based on the depth of the $15^{\circ} \mathrm{C}$ isotherm is used. The depth of this isotherm is an indicator of the depth of the thermocline in temperate latitudes. The depths of the seasonal thermocline determined using both logistic function and $15^{\circ} \mathrm{C}$ isotherm show a good agreement. Likewise, the two methods used to determine the MLD thickness give similar results, the base of the MLD being located in average 15-20 m above the mean thermocline depth. From now on, we will focus on the analysis of the seasonal thermocline estimated by the logistic function. The main advantage of using the depth of the seasonal thermocline to study the effects of eddies in the water column is that it does not depend on absolute values or fixed thresholds criteria. Thus, it provides a more robust methodology to analyse the vertical variations of the thermocline in and outside the eddies.

\subsection{Calculation of the vorticity fields and vertical velocities}


Dynamic height (dh) profiles, between adjacent stations, were computed using a reference level of no motion at $900 \mathrm{dbar}$ (deepest available level with acceptable spatial coverage). Since the sampling strategy was optimized to resolve properly the anticyclone, calculation of derived variables that requires the analysis of 3D hydrographic fields (i.e. vertical velocities) can be only obtained with the adequate accuracy for this structure. Horizontal fields of dh were obtained by objective analysis of the along-track profiles using the Optimal Statistical Interpolation (OSI) scheme described in Gomis et al. (2001) and Allen et al. (2001), in a regular 18x23 grid centred on the anticyclone and with regular node distances of $0.05^{\circ}$. This scheme analyses observation increments, i.e., the difference between the observations and the background field (Gomis et al., 2001). In our case, the background estimated using a local 1st order degree polynomial least square fits to the observations. Then, a simple Gaussian function for the correlation model between observations (assuming 2D isotropy) is set up, with a correlation length scale of $16 \mathrm{~km}$, chosen according to $\mathrm{dh}$ profiles correlation statistics obtained at different depths. A noise to signal variance ratio for the analysis of dynamic heights of 0.0027 was used. This ratio is defined as the variance of the observational error divided by the variance of the interpolated field (the latter referring to the deviations between observations and the mean field). This parameter allows to include in the analysis an estimation of the observational error and to adjust the weight of the observations on the analysis (the largest the noise to signal parameter, the smallest the influence of observations). Finally, all fields were spatially smoothed, with an additional low-pass filter with a cut-off length scale of $16 \mathrm{~km}$, in order to avoid aliasing errors due to unresolved structures.

To obtain 3D matrix fields, in order to compute derived variables, horizontal analyses were performed independently at $10 \mathrm{dbar}$ intervals. Geostrophic velocities $\left(u_{g}, v_{g}\right)$ were obtained by the first-derivative of the $2 \mathrm{D}$ dh interpolated fields. Then, horizontal quasigeostrophic relative vorticity is obtained at a given $z$ level as:

$$
\xi_{g z}=\frac{\delta v_{g}}{\delta x}-\frac{\delta u_{g}}{\delta y}
$$

Quasi-geostrophic vertical velocities, $w_{\mathrm{qg}}$, are obtained using the omega equation (Hoskins et al., 1978; Gomis and Pedder, 2005), in a similar approach to that used in Ruiz et al. (2014). In our case, the upper, lower and lateral boundaries have been set as $w_{\mathrm{qg}}=0$. For a detailed study on the use of the Omega equation to diagnose vertical motions in the ocean, see Pinot et al. (1995).

And finally the Ekman pumping was computed from the equation described in Gaube et al. (2015):

$$
W_{E}=-\frac{3 \rho_{a i r} C_{d}\left|U_{a i r}\right|}{2 \rho_{0} f} \xi_{g z}
$$

And by applying the same parameters, that is an air density $\left(\rho_{\text {air }}\right)$ of $1.2 \mathrm{~kg} \mathrm{~m}^{-3}$, seawater density $\left(\rho_{0}\right)$ of $1020 \mathrm{~kg} \mathrm{~m}^{-3}$ and a drag coefficient $\left(C_{d}\right)$ of 0.001 . The Coriolis parameter $(f)$ has been computed for the latitudes of the study area; wind speed $U_{\text {air }}$ is an average of the $10 \mathrm{~m}$ high winds flowing over the study area during the mission, and finally, the relative vorticity used is that obtained by the OSI scheme at $50 \mathrm{~m}\left(\xi_{g z=50}\right)$. The relative vorticity at $50 \mathrm{~m}$ has been used, because at this depth one can expect that vorticity provides a good description of the internal dynamics of the eddy (avoiding the effect of the wind over the shallower levels). Then, the tilting of the dh levels within the eddy are assumed to be constant within the first $50 \mathrm{~m}$. 
Wind data has been obtained from outputs provided by MeteoGalicia (meteorological agency of Galicia Spanish region). The hourly and $12 \mathrm{~km}$ horizontal resolution wind data result from the Weather Research and Forecasting atmospheric numerical model (WRF, see details in Skamarock et al., 2005), which reproduces with a reasonable accuracy offshore winds in the Bay of Biscay (Ferrer et al., 2010).

\subsection{Satellite data}

Before the beginning of the mission and during it, satellite information was continuously collected and analysed in near real time. Even if the glider was configured for saving battery, it was a key point to know prior to the start of the mission the approximate position of the 4W SWODDY. The eddy was centred on abyssal waters and there was not any moored instrument measuring in that area. Therefore, the unique way for locating it was by means of satellite data. SST and Chl-a images covering the Bay of Biscay were processed from a month before the beginning of the mission to the end of it. Daily Level 2 SST images were derived from the AVHRR sensor series $(1 \mathrm{~km}$ resolution); and level $2 \mathrm{Chl}$-a images were obtained by MODIS-AQUA satellite $(1 \mathrm{~km}$ resolution).

Two different types of Sea Level Anomaly (SLA) and Geostrophic Current Anomaly (GCA) maps distributed by AVISO (http://www.aviso.oceanobs.com/) have been used. First of all, before and during the mission, global-near real time-updated and merged $1 / 3^{\circ}$ Mercator grid maps were selected. After the mission and when available to the community, delayed products were analysed. These delayed data include the last improvements made on the altimetry data that comprise among others, Cartesian $14^{\circ}$ resolution and different filtering and sub-sampling along track products geophysical content (AVISO, 2014 Updated maps were optimally interpolated from along track data (Le Traon et al., 1998; Ducet et al., 2000) recovered by the maximum number of satellites available for the study period, in this case Jason-1 in its Geodetic Phase, SARAL/Altika, Cryosat-2, and Jason-2, for recovering more accurately mesoscale structures (Pascual et al., 2006).

\section{Results and discussion}

\subsection{Eddies observation during GESEBB mission}

Vertical distribution of temperature in the first $200 \mathrm{~m}$, measured by the glider along its tracks during part of the GESEBB mission, is shown in Figure 2. The mean depth of the thermocline was of $30 \mathrm{~m}$. The anomalies generated by the eddies are easily identified down to deep levels (more than $600 \mathrm{~m}$ ) and, as it will be discussed later, they induce significant changes in the depth of the mixed layer and of the seasonal thermocline. 

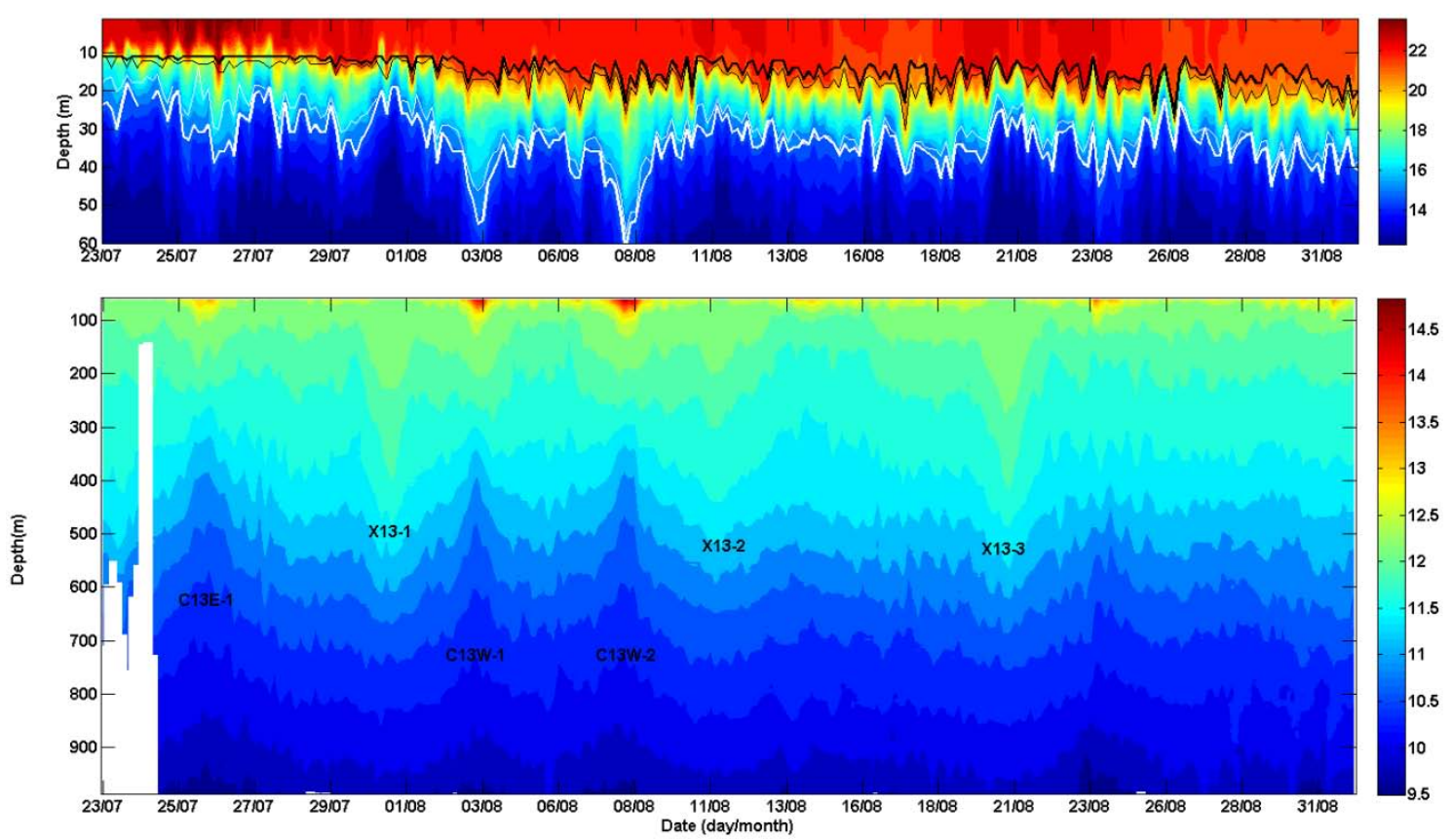

Figure 2: Vertical potential temperature distribution along the glider track from the surface to $60 \mathrm{~m}$ depth (upper panel) and from $60 \mathrm{~m}$ to the maximum depth covered by the glider, i.e. $1000 \mathrm{~m}$ (lower panel). The depth of the MLD as inferred by two different methods is superimposed (black bold line: $0.2^{\circ}$ threshold method; black solid line: $1^{\circ}$ threshold method) to the temperature distribution of the upper panel, as well as the depth of the seasonal thermocline estimated by two methods (white bold line: depth of $15^{\circ}$ isotherm and white solid line: logistic fit method). The names of the eddies are superimposed to the temperature distribution of the lower panel.

The following table lists the eddies crossed by the glider during the mission and the COE detected by the method from Nencioli et al. (2008), applied to the vertically integrated currents. Three different structures are observed, two cyclones and one anticyclone (C13E, C13W and X13, respectively). For naming the eddies we have followed the rule used by Pingree and Le Cann (1992a; 1992b); that is, X13 for the anticyclone, because the generation place it is not known with certainty, the numbers indicate the year of detection; the cyclones are indicated with a "C" plus the year and the position (East or West) they occupy with respect to X13.

The maximum depth of the $11.5^{\circ} \mathrm{C}$ isotherm varies significantly among structures: in the cyclones this isotherm is located from 88 to $113 \mathrm{~m}$ above the mean, whilst it is located from 69 to $103 \mathrm{~m}$ below in the anticyclones.

\begin{tabular}{|c|c|c|c|c|c|c|c|c|c|c|}
\hline \multicolumn{2}{|c|}{ Date } & \multirow{2}{*}{ Name } & \multirow{2}{*}{$\begin{array}{c}\text { Pass } \\
\text { number of } \\
\text { the } \\
\text { structures }\end{array}$} & \multicolumn{2}{|c|}{$\begin{array}{c}\text { Centre Of Eddy } \\
\text { (Nencioli et al., 2008) }\end{array}$} & \multicolumn{2}{|c|}{$11.5^{\circ} \mathrm{C}$ Isotherm } & \multicolumn{2}{|c|}{$\begin{array}{l}\text { Max. geost. } \\
\text { speeds }\left(\mathrm{cm} \mathrm{s}^{-1}\right)\end{array}$} & \multirow{2}{*}{$\begin{array}{l}\text { Eddy } \\
\text { diam. } \\
(\mathbf{k m})\end{array}$} \\
\hline Initial & Final & & & Latitude & Longitude & $\begin{array}{l}\text { Depth } \\
(\mathrm{m})\end{array}$ & $\begin{array}{c}\text { Anomaly } \\
(\mathrm{m})\end{array}$ & + & - & \\
\hline $24 \mathrm{Jul}$ & $\begin{array}{l}27 \\
\text { Jul }\end{array}$ & C13E & C13E-1 & 44.00 & -2.72 & 294 & -113 & 32.0 & -14.3 & 56 \\
\hline $30 \mathrm{Jul}$ & $\begin{array}{c}2 \\
\text { Aug }\end{array}$ & $\mathrm{X} 13$ & $\mathrm{X} 13-1$ & 44.54 & -3.40 & 495 & +88 & 10.4 & -14.4 & 57 \\
\hline 2 Aug & $\begin{array}{c}5 \\
\text { Aug } \\
\end{array}$ & C13W & C13W-1 & 44.25 & -4.01 & 334 & -73 & 21.3 & -23.0 & 44 \\
\hline 6 Aug & $\begin{array}{c}9 \\
\text { Aug } \\
\end{array}$ & C13W & C13W-2 & 44.20 & -4.05 & 320 & -87 & 32.8 & -19.1 & 52 \\
\hline 9 Aug & $\begin{array}{c}12 \\
\text { Aug } \\
\end{array}$ & $\mathrm{X} 13$ & $\mathrm{X} 13-2$ & 44.62 & -3.52 & 476 & +69 & 10.2 & -6.4 & 75 \\
\hline $\begin{array}{c}19 \\
\text { Aug }\end{array}$ & $\begin{array}{c}22 \\
\text { Aug }\end{array}$ & $\mathrm{X} 13$ & $\mathrm{X} 13-3$ & 44.74 & -3.64 & 510 & +103 & 21.5 & -12.1 & 53 \\
\hline
\end{tabular}


Table 1. List of the times the different eddies were observed, indicating the initial and final date of observation, the name, the pass number of each structure, the estimated position of the centre, the maximum depth of the $11.5^{\circ} \mathrm{C}$ isotherm, the maximum speeds of the geostrophic currents, and the estimated diameters.

The vertical density profiles of the first passes of the 3 different structures (Fig. 3), in addition to the vertical displacement of the $11.5^{\circ} \mathrm{C}$ isotherm, also show different patterns in the vertical displacement of the isopycnals between the cyclones and the anticyclone, according to what is observed in temperature profiles (Fig. 2). Thus, 27.5 to 27.2 isopycnals move upwards around the centre of the cyclones; whilst, from 27.1 to the surface, the isopycnals tend to move downwards (Fig. 3, Right and Centre). In contrast, around the centre of $\mathrm{X} 13$, deepest isopycnals (from 27.4 to 27.1 ) migrate downwards and shallower isopycnals (from 27.0 to the surface) migrate upwards (Fig. 3, Right).
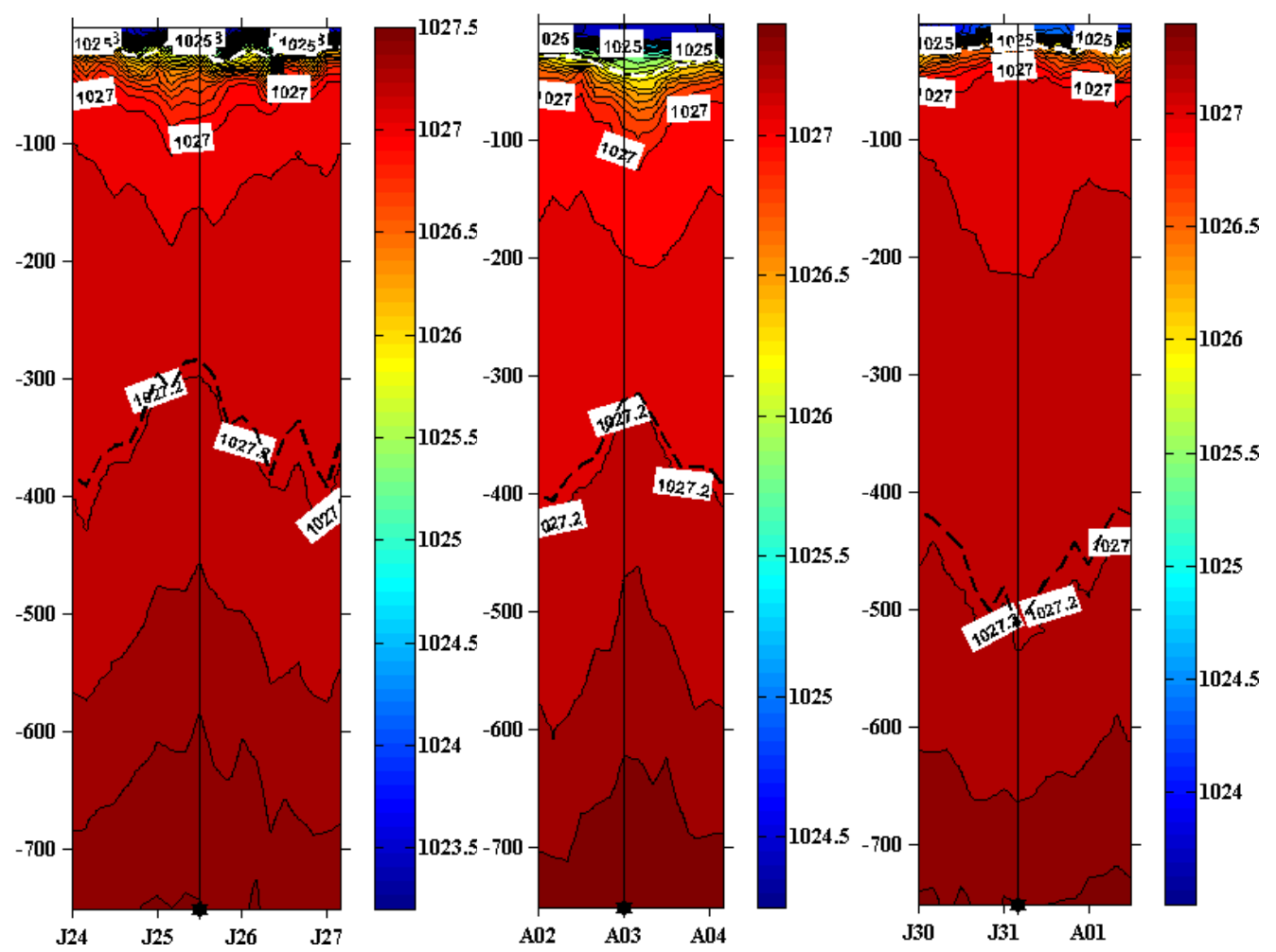

Figure 3: Density $\left(\sigma_{\odot}\right)$ vertical sections from the surface to $750 \mathrm{~m}$ depth, along the first passes of the glider across the C13E (C13E-1, Left), C13W (C13W-1, Centre) and X13 (X13-1, Right) eddies. White dashed lines in indicate the depth of the seasonal thermocline and black dashed lines the depth of the $11.5^{\circ} \mathrm{C}$ isotherm. The COE is indicated with a star.

Geostrophic currents variability as a function of depth and longitude, estimated from the density profiles and assuming a reference level at $1000 \mathrm{~m}$ depth, is presented for the C13E-1, C13W-1 (Fig. 4, Up) and X13-1 (Fig. 4, Bottom). The vertical profiles of the geostrophic currents, also confirm the cyclonic and anticyclonic nature of these eddies. 

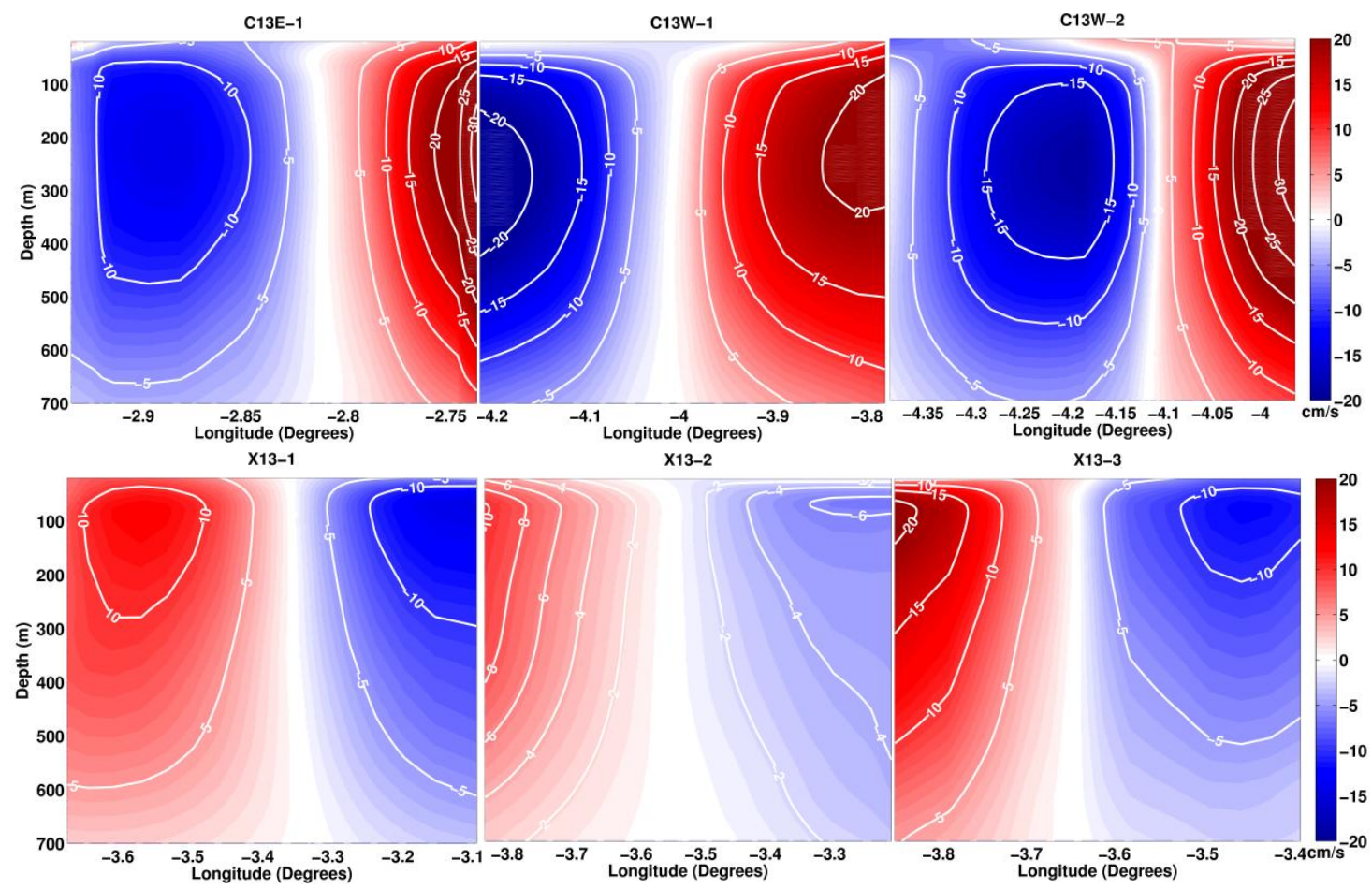

Figure 4: Vertical sections of the geostrophic currents from the surface to $700 \mathrm{~m}$ depth measured by the glider along its unique pass (C13E-1), first and second pass (C13W-1 and C13W-2) and first, second and third pass (X13-1, X13-2, and X1-3) across, C13E, C13W and X13 eddies, respectively.

Figure 5 shows the MSLA maps corresponding to the first (Fig. 5, Left) and second (Fig. 5, Right) glider transects. Overlapped to these figures, the vertically integrated currents and the COE are also plotted. In both cases, the glider sampled X13 near the same position $\left(44.5^{\circ} \mathrm{N} 3.5^{\circ} \mathrm{W}\right) . \times 13$ is observed during all the study period. The anticyclone remains quasi stationary (it follows a slow north-westward drift of the COE) during more than 3 weeks and it is observed to be interacting with at least two cyclonic structures. With regard to the cyclones, probably due to their proximity to the coast and because they are smaller (Table 1), they are not detected as closed structures in the MSLA maps. During the first transect the glider crossed C13E, whose centre is indicated by a pink point (Fig. 5, Left). The SST image corresponding to some days before shows a colder signal near this point (Fig. 6, Left), which has not be observed by the glider, probably due to the time lag between the image and the glider transect and the distance of the transect to the COE. However, the altimetry shows a cyclonic structure North-East of it (Fig. 5, Left). The altimetry maps show a better agreement with the glider measurements during the second transect, when it crosses X13 and C13W (Fig. 5, Right). The SST image within the period of the transect shows a strong thermal front in the estimated southern and eastern periphery of the structure; placing warmer waters in the southern and eastern periphery and colder waters on the core (Fig. 6, Centre). This is in agreement with the altimetry map that during this date, locates the southern periphery of an anticyclone near the front (Fig. 5, Right). With regard to $\mathrm{C} 13 \mathrm{~W}$, the Chl-a map corresponding to two weeks before the glider transect (18 July 2013) captured an anticlockwise meandering with a relative maximum of Chl-a near the COE (Fig. 6, Right). 

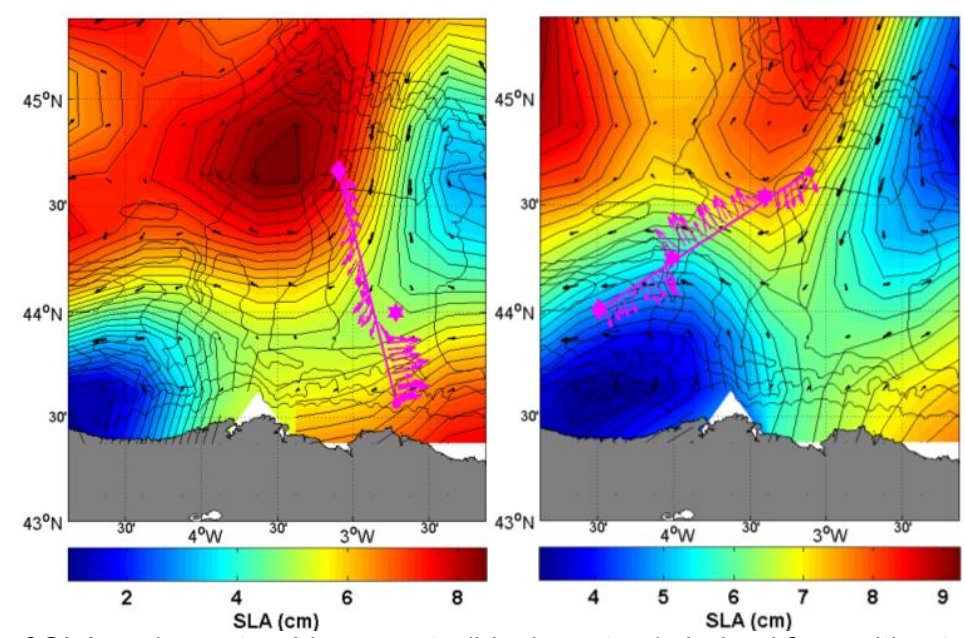

Fig. 5: (Left) Map of SLA and geostrophic currents (black vectors) derived from altimetry, corresponding to 26 July 2013, vertically integrated currents measured from the glider (pink vectors) during the first transect and the COE of C13E (pink stars) is superimposed to the map. (Right) Map of SLA and geostrophic currents derived from altimetry, corresponding to 3 August 2013, vertically integrated currents measured from the glider during the second transect and the COE of $X 13$ and C13W (pink points) are superimposed to the map. The first (pink point) and last (pink diamond) positions of the tracks are indicated in the plots. Isobaths (m): 200, 1000, 2000, 3000 and 4000. *Note: Altimetry maps correspond to dates within the time period of the transect

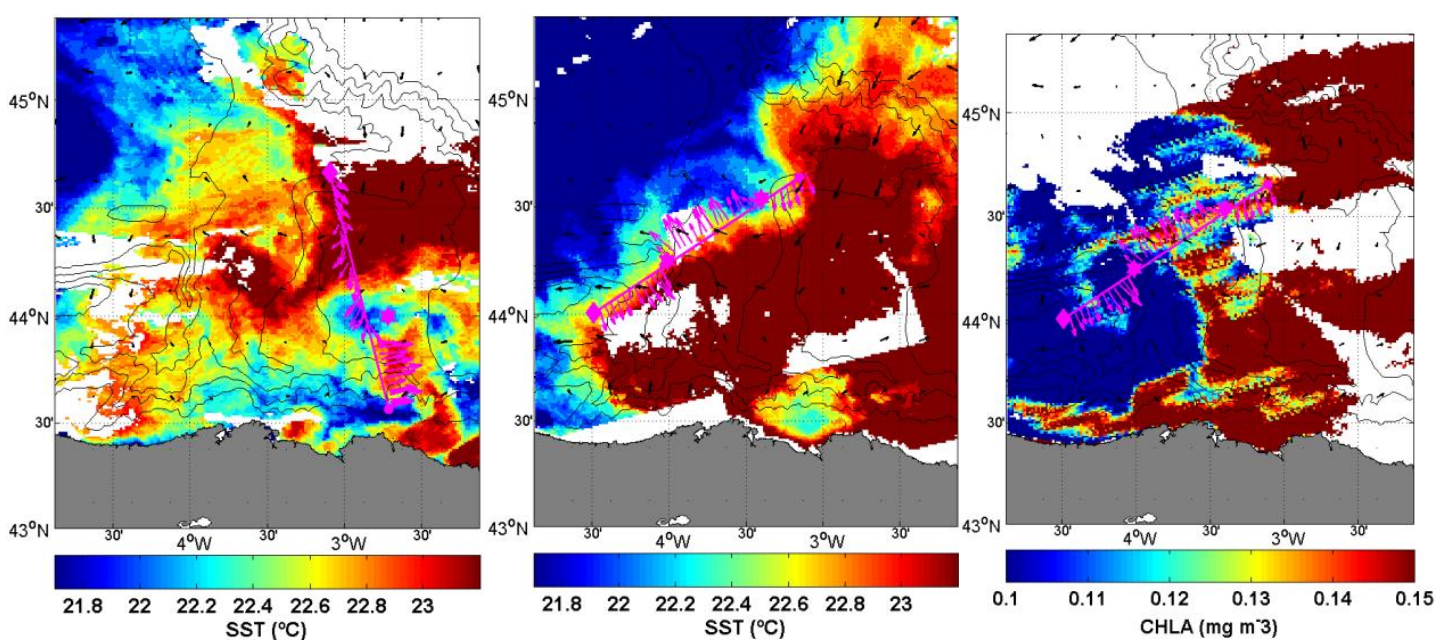

Fig. 6: (Left) SST image of 19 July 2013, vertically integrated currents measured from the glider during the first transect (pink vectors) and the COE of a C13E (pink stars). (Centre) SST image of 30July 2013 and (Right) Chl-a image of 18 July 2013 and vertically integrated currents measured from the glider during the second transect and the COE of X13 and C13W (pink stars). The first (pink point) and last (pink diamond) positions of the tracks are indicated in the plots. Isobaths (m): 200, 1000, 2000, 3000 and 4000. *Note: the SST and Chl-a images and geostrophic currents (black vectors) derived from altimetry, correspond to dates within the time period of the superimposed transect.

\subsection{Main characteristics of the cyclonic eddies}

According to the COE method, the centre of C13E was not surveyed by the glider. The transect crossed, instead, an area between the core and the periphery (Fig. 7a). With regard to the temperature and salinity, the isotherms and isohalines are depressed (star and line) from the surface to at least $100 \mathrm{~m}$ depth and the depth of the seasonal thermocline (indicated with a white line) slightly increases (Fig. 7ef). Conversely, TS isolines from around $300 \mathrm{~m}$ to at least $750 \mathrm{~m}$ depth are rising, and they have a significant impact on the depth of the $11.5^{\circ} \mathrm{C}$ isotherm (Fig. $7 \mathrm{bc}$ ). 
a)

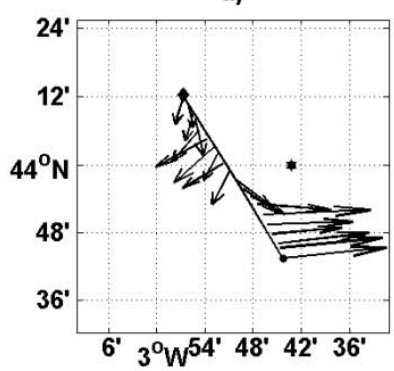

d)

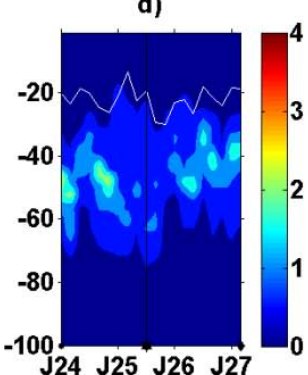

b)

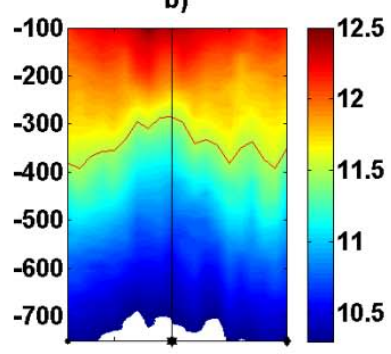

e)

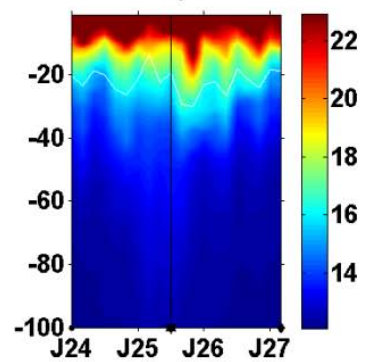

c)

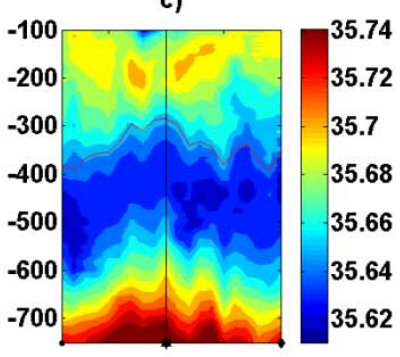

f)

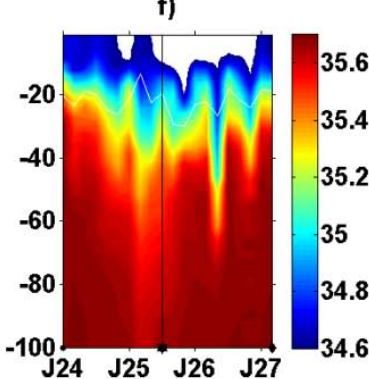

Figure 7: a) Vertically integrated currents along C13E-1 (see Fig. 1, from WP0 to WP1). The first (black point) and last (black diamond) position of the track is indicated in the plot, whilst the COE is indicated with a star. $b$-c) Temperature $\left({ }^{\circ} \mathrm{C}\right)$ and salinity vertical section along the transect from 100 to $750 \mathrm{~m}$ depth. $d$-f) $\mathrm{Chl}$-a fluorescence $\left(\mu \mathrm{g} \Gamma^{-1}\right)$, temperature $\left({ }^{\circ} \mathrm{C}\right)$ and salinity from surface to $100 \mathrm{~m}$ depth. White lines in $d-f$ indicate the depth of the seasonal thermocline and the red lines in $b$ and $c$, the depth of the $11.5^{\circ} \mathrm{C}$ isotherm.

The core and the base of the ENACW are centred on $200 \mathrm{~m}$ and $500 \mathrm{~m}$, respectively. The core is characterized by saline and warm water and the base by a minimum of salinity and cold water. It can be observed that there are two relative maxima of salinity on both sides of the COE of C13E-1, within the core of the ENACW. Below the base of the ENACW the salinity increases, indicating the influence of the MW. The maximum Chl-a fluorescence, an indicator of the DCM, is located below the seasonal thermocline; maximum values are observed between the COE and the periphery of the cyclone (Fig. 7d). The maximum geostrophic currents are centred around $250 \mathrm{~m}$ depth and reach values of $32 \mathrm{~cm} \mathrm{~s}^{-1}$ (Fig. 4 and Table 1).

$\mathrm{C} 13 \mathrm{~W}$ was located at the south-western corner of the study area. Unlike C13E that was crossed only at the beginning of the campaign, during the first transect, $\mathrm{C} 13 \mathrm{~W}$ was surveyed twice during the study period (Table 1). In addition, the COE method indicates that the structure was crossed near its centre (Fig. 8a). The location of the seasonal thermocline in $\mathrm{C} 13 \mathrm{~W}-1$ reaches greater depths, around $45 \mathrm{~m}$ depth (Fig. 8d-f) than in C13E-1. The downlift of the seasonal thermocline is clearer than in C13E-1. $11.5^{\circ} \mathrm{C}$ isotherm is also uplifted near the COE (Fig. 8bc). In both cases, these differences amongst $\mathrm{C} 13 \mathrm{E}-1$ and $\mathrm{C} 13 \mathrm{~W}-1$ can be partially related to the relative position of the transect to the COE. The two relative maxima of salinity on both sides of the COE within the core of the ENACW are also observed in C13W-1 (Fig. 8c). With regard to the Chl-a fluorescence (Fig. 8d), it is higher below the thermocline and appears to increase at the periphery as observed in the corresponding satellite Chl-a image (Fig. 6, Right). 
a)

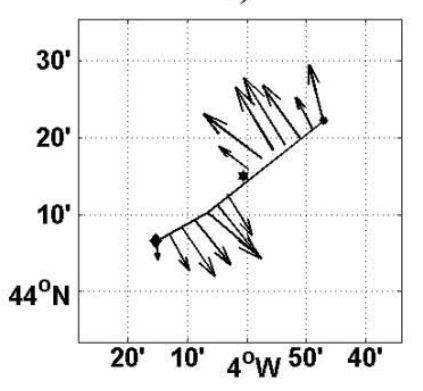

d)

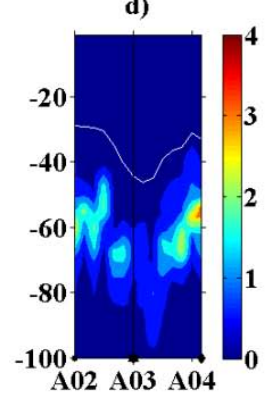

b)

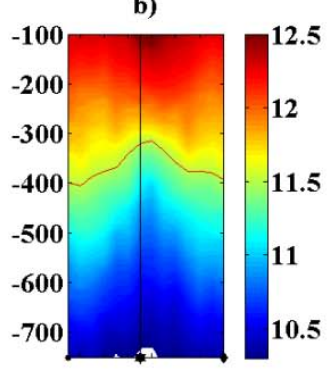

e)

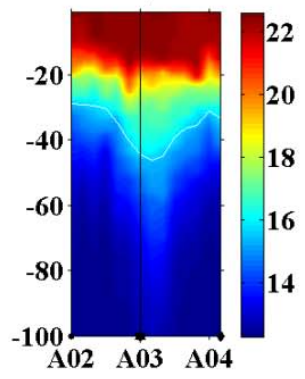

c)

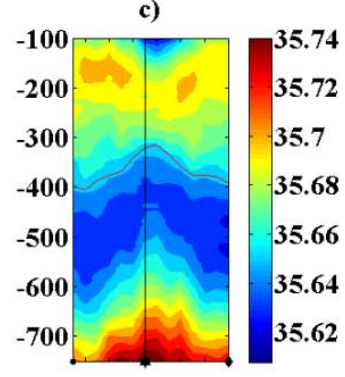

f)

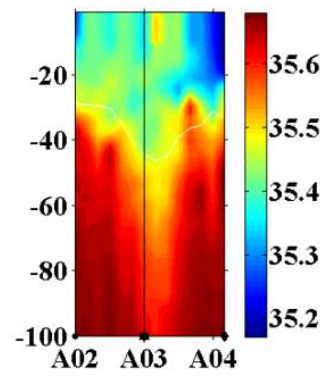

Figure 8: a) Vertically integrated currents along C13W-1 (see Fig. 1, from WP1 to WP2). The first (black point) and last (black diamond) position of the track is indicated in the plot, whilst the COE is indicated with a star. b-c) Temperature $\left({ }^{\circ} \mathrm{C}\right)$ and salinity vertical section along the transect from 100 to $750 \mathrm{~m}$ depth. $d$-f)

$\mathrm{Chl}$-a fluorescence $\left(\mu \mathrm{g} \mathrm{\textrm {I } ^ { - 1 }}\right)$, temperature $\left({ }^{\circ} \mathrm{C}\right)$ and salinity from surface to $100 \mathrm{~m}$ depth. White lines in $\mathrm{d}-\mathrm{f}$ indicate the depth of the seasonal thermocline and the red lines in $b$ and $c$, the depth of the $11.5^{\circ} \mathrm{C}$ isotherm.

The geostrophic currents of $\mathrm{C} 13 \mathrm{~W}$ corresponding to the two passes of this glider across it (Fig. 4), confirm its cyclonic nature and that the glider crossed it around $2.81^{\circ} \mathrm{W}$. The maximum geostrophic currents $\left(\sim 33 \mathrm{~cm} \mathrm{~s}^{-1}\right.$; see Fig. 4 and Table 1$)$ are centred around $250 \mathrm{~m}$ depth and reach values slightly higher than in the case of the eastern cyclone (again, probably related to the different position of the transects with respect to the COE).

In terms of vertical properties, within both cyclones the isotherms and isohalines are depressed from surface to at least $100 \mathrm{~m}$ depth while they rise at deeper levels, from around $300 \mathrm{~m}$ to at least $750 \mathrm{~m}$ depth. This particular behaviour is characteristic of the cyclonic thinnies, where upward displacement of the main thermocline and downward displacement of the seasonal thermocline result in a thinning of the mode water layer of the eddy. This is the common structure of cyclonic after interaction with winds. Eddywind-driven downwelling is induced at their shallower levels through different mechanisms (Gaube et al., 2015). Since the signal of the main thermocline dominates, these cyclones maintain a negative anomaly in MSLA, thus been detectable as cyclonic structures (Fig. 5). Since the downwards displacement of surface isopycnals is opposite to the geostrophic interior dynamics of these cyclones, surface relative vorticity after wind-eddy interactions is reduced. This could explain the lower geostrophic velocities observed at shallower levels in both cyclones (Fig. 4). Also, the eddy-wind downwelling at the shallower levels could be expected to reduce the Chl-a concentration at the centre of these structures, in agreement with what is observed in Figures 7 and 8 , and in opposition to what could be expected for a cyclone characteristic of the first baroclinic mode (McGillicuddy, 2015).

\subsection{Characteristics of $\mathrm{X} 13$ and estimation of vertical velocities}

X13 was crossed three times (Table 1), passing through different parts of the structure. The glider crossed X13-1 near the COE (Fig. 9a). In comparison with the cyclones, an 
opposite behaviour is observed in the water column: the seasonal thermocline is uplifted near its centre (Fig. $9 \mathrm{~d}-\mathrm{f}$ ), whereas the $11.5^{\circ} \mathrm{C}$ isotherm is depressed in the COE (Fig. 9bc). This is the typical vertical signal of a mode-water eddy (McGillicuddy et al., 1999). A maximum of salinity near the COE can be observed. This is a characteristics of SWODDIES (Pingree and Le Cann, 1992a, b; Garcia-Soto et al., 2002), often observed as lens-like eddies centred at about $200 \mathrm{~m}$. The maximum salinity is observed on the core profiles, located around 200 dbar and its value is 35.7 ; the same salinity is observed by Sánchez and Gil (2004) for the AE6 SWODDY in August 1998. The maximum temperature of $X 13-1$ core is $12.5^{\circ} \mathrm{C}$, a value near the range observed by the latter authors. The Chl-a fluorescence is also located below the seasonal thermocline and it is significantly stronger than inside the two cyclones, with the highest values observed near the COE. During the formation and intensification of mode-water eddies, the shoaling of the seasonal pycnocline displaces nutrients to the euphotic layer, intensifying the primary production at depth (McGillicuddy et al., 2007).

a)

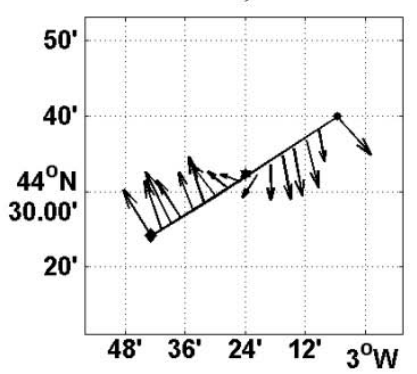

d)

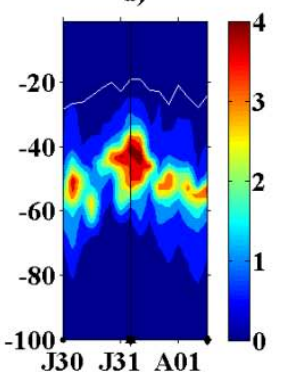

b)

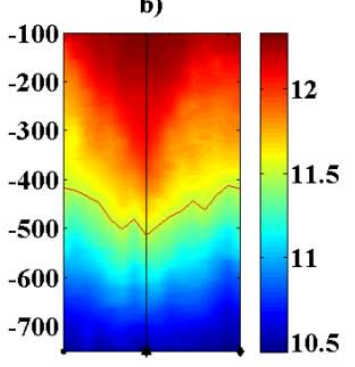

e)

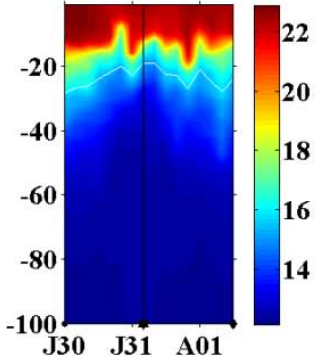

c)

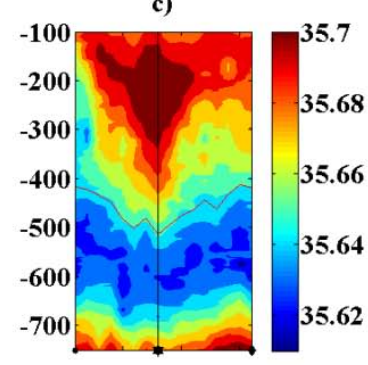

f)

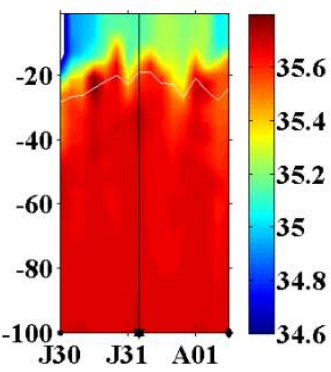

Figure 9: a) Vertically integrated currents along X13-1 (see Fig. 1, from WP1 to WP2). The first (black point) and last (black diamond) position of the track is indicated in the plot, whilst the COE is indicated with a star. b-c) Temperature $\left({ }^{\circ} \mathrm{C}\right)$ and salinity vertical section along the transect from 100 to $750 \mathrm{~m}$ depth. $d$-f)

$\mathrm{Chl}$-a fluorescence $\left(\mu \mathrm{g} \Gamma^{-1}\right)$, temperature $\left({ }^{\circ} \mathrm{C}\right)$ and salinity from surface to $100 \mathrm{~m}$ depth. White lines in $\mathrm{d}-\mathrm{f}$ indicate the depth of the seasonal thermocline and the red lines in $b$ and $c$, the depth of the $11.5^{\circ} \mathrm{C}$ isotherm.

The geostrophic currents of X13, corresponding to the three passes of the glider across it (Fig., 4), confirmed its anticyclonic nature. It is also confirmed a migration of the centre of this structure with time; since whilst during the first glider-pass the centre was located around $3.35^{\circ} \mathrm{W}$, in the last glider-pass (carried out 20 days after) it was located around $3.68^{\circ} \mathrm{W}$. In contrast to the cyclones, the maximum geostrophic currents are centred at shallower depths, at around $100 \mathrm{~m}$ depth, although similarly (and also likely related to the effects of wind-eddy interactions) the geostrophic velocities significantly decrease at the shallowest levels. In addition the maxima $\left(\sim 22 \mathrm{~cm} \mathrm{~s}^{-1}\right.$; see Fig. 4 and Table 1) are smaller than that observed for the cyclones.

The glider sampling for $\mathrm{X} 13$ was dense enough for reconstructing 3D fields, in order to provide further understanding of the physical processes responsible for the vertical structure of this eddy. Vertical velocities were computed following two different approximations as detailed in Section 2.3 (Fig. 10). On the one hand, the quasigeostrophic vertical currents from the Omega equation at $55 \mathrm{~m}$ and $75 \mathrm{~m}$ depths (Fig. 
$10 \mathrm{ab}$ ) indicate that maximum Wqg occur along the periphery of the structure; with down and upwelling velocities of the order of several $\mathrm{m} \mathrm{day}^{-1}$. It appears that there is an alternation of positive and negative values along the periphery, in accordance with high resolution observation of Wqg within oceanic eddies in front of the western African coast (Ruiz et al., 2014).

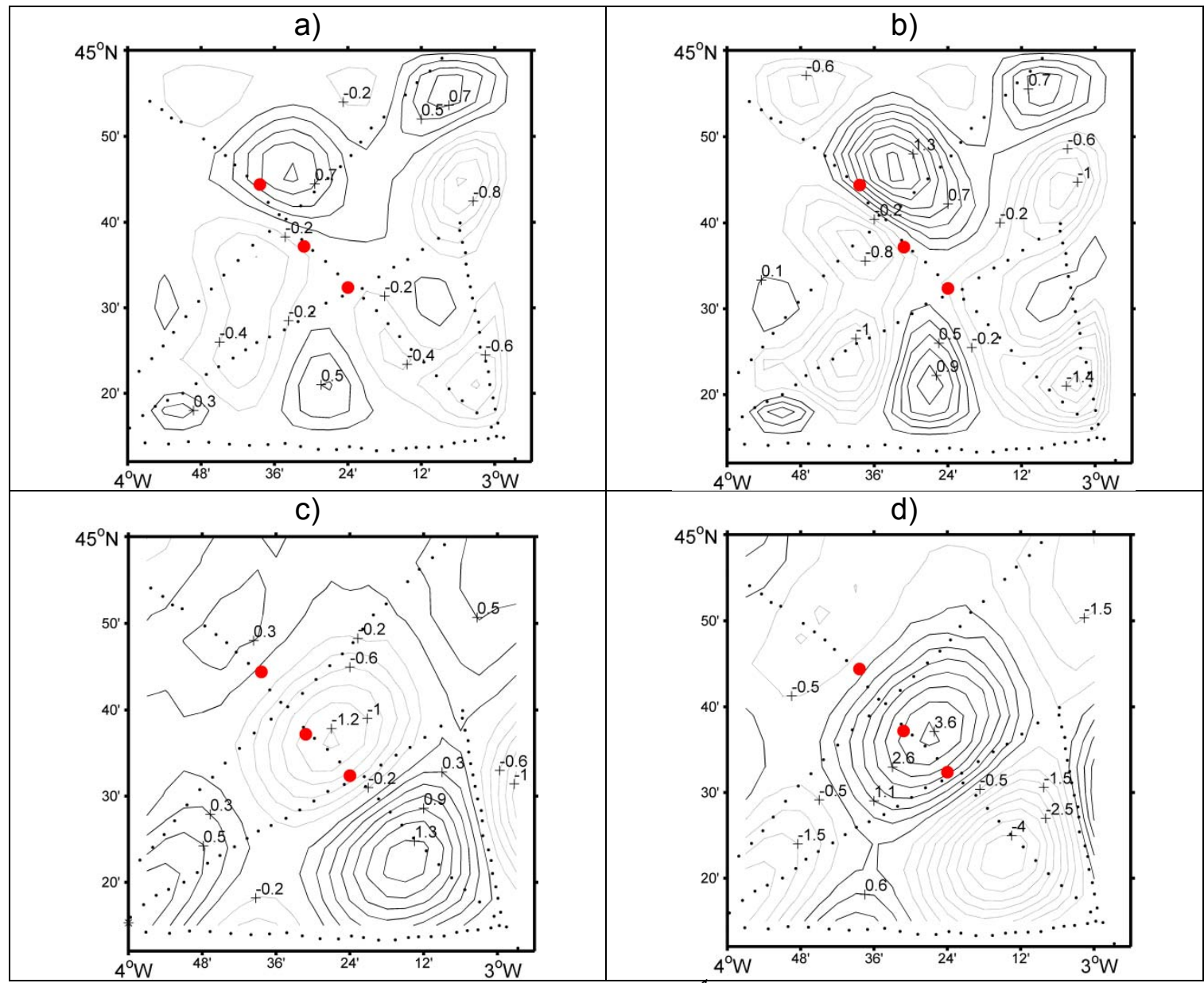

Figure 10. Quasi-geostrophic vertical velocities (Wqg, $\mathrm{m} \mathrm{day}^{-1}$ ) at (a) 55 and (b) $75 \mathrm{~m}$ depth; Geostrophic relative vorticity (units * $\left.10^{-5} \mathrm{~s}^{-1}\right)(c)$ and $W_{E}\left(\mathrm{~cm} \cdot\right.$ day $\left.^{-1}\right)(\mathrm{d})$, at $50 \mathrm{~m}$. The transects of the glider (points) considered for the computation of $3 D$ fields. Red circles indicate the COEs of X13.

On the other hand, since the vertical structure of the X13 indicates eddy-wind induced upwelling, Ekman Pumping $\left(\mathrm{W}_{\mathrm{E}}\right)$ has been estimated by using the parameters detailed in Section 2.3, wind conditions during the campaign and the quasi-geostrophic relative vorticity at $50 \mathrm{~m}$ depth (Fig. 10c). The wind regime, flowing over study area and during the mission, was predominantly south-eastward. Average wind speeds throughout the study period ranged between 1.8 and $2.2 \mathrm{~m} \mathrm{~s}^{-1}$. This mean wind flow has been used for a qualitative view of the Ekman pumping variability and order. $W_{E}$ is shown in Figure $10 \mathrm{~d}$. Maximum upwelling velocities are observed in the core of $X 13$ (with magnitudes of $0.04 \mathrm{~m} \mathrm{day}^{-1}$ ). The results obtained are consistent with the magnitude of the Ekman pumping observed by McGillicuddy (2015) and Gaube et al. (2015) for similar eddies. These authors found velocities slightly more intense $\left(0.1 \mathrm{~m} \mathrm{day}^{-1}\right)$, which was expected since in our case wind speed is four times lower than that used by McGillicuddy (2015). If wind conditions from the beginning of May, when the formation of the seasonal thermocline usually occurs (Rubio et al., 2013), to the end of the study period are used as input for computing Ekman pumping, an upwelling of $6.1 \mathrm{~m}$ is obtained. This result is close to what is observed by the glider (Fig. 9 and Table 2). 
Finally, it is worth noting that the magnitude of the vertical currents induced by Ekman Pumping (several $\mathrm{cm}_{\text {day }}^{-1}$ ) is two orders of magnitude lower than that from the Omega equation (several $\mathrm{m}_{\text {day }}{ }^{-1}$ ). The combined effect of these two forcings can be used to better understand the vertical Chl-a fluorescence distribution observed in X13. Whilst the maximum values observed in the eddy core and shallower levels (40-50 m) could be related with the eddy-wind induced upwelling at the COE, the high values observed around the eddy periphery could be the result of the vertical displacements induced by quasi-geostrophic dynamics.

\subsection{Hydrography and Chl-a fluorescence inside and outside of the eddies}

The $\Theta-S$ diagram, corresponding to all the data collected during the study period and colour-coded according to the depth (Fig. 11a), shows that there is a significant variability from the surface to the 27.1 isopycnal. Between the 26 and 27 isopycnals there are some points that despite having similar hydrographic properties occupy deeper waters (>100 m depth) than the water masses around ( $<100 \mathrm{~m}$ depth). This deepening of the water masses is associated with the dynamics of cyclonic eddies, as it will be demonstrated later. The 27.1 isopycnal is marked with a dashed line; it is recognized in the literature as the shallowest limit of core of the ENACW (Somavilla et al., 2009). The central (27.2) and deepest (27.3) limits are also shown with dashed lines. In this case, the shallower limit is observed between 200 and $300 \mathrm{~m}$ depth. The base of the ENACW, can be recognized in the $\Theta-S$ diagrams from the minimum salinity value around 27.2 isopycnal and near $500 \mathrm{~m}$ depth, as it has been observed in the previous Section. Its position is in agreement with the values observed for the NACW in the Cap Ferret area (Valencia et al., 2004, see figure 11a). Beneath the potential density of 27.3, the influence from MW begins and the salinity of deeper waters increase. Above the permanent thermocline (from 200-300 dbar to surface, and above the 27.1 isopycnal or the upper limit of the NACW), the dispersion in terms of $\Theta-$ $S$ values is much higher, as a result of other increased mixing processes, as internal waves. The highest $\Theta-S$ variability is observed in the first $100 \mathrm{~m}$, above the 27 isopycnal. The $\Theta-S$ values of the water masses contained in the three analysed structures are highlighted over the whole water masses $\Theta-S$ in Figure $11 \mathrm{c}-\mathrm{d}$. As it can be observed, the maximum temperatures (from 23 to $24^{\circ} \mathrm{C}$ ) near the surface are reached inside $\mathrm{C} 13 \mathrm{E}$. This could be due to the seasonal warm pool that is generally located at the south-east corner of the Bay, near the area where C13E was sampled by the glider, and that could affect temperatures in the shallowest waters within the cyclone. The salinity over the ENACW within this cyclone is near the lowest values observed during the study period. This could indicate an input of fresh water in the surface layer of the structure. Near $1000 \mathrm{~m}$ depth C13E reaches the lowest temperatures, in comparison with the remaining structures. Near the surface of X13 and along the three different passes, although the temperature profiles show low variation (temperature ranges between $22^{\circ} \mathrm{C}-23^{\circ} \mathrm{C}$ ), the salinity shows more variability from less than 34 (values reached during the second time the structure is crossed by the glider) to 35.3. The two passes through $\mathrm{C} 13 \mathrm{~W}$ present similar hydrographical conditions from surface to $1000 \mathrm{~m}$. This result was expected, since the two transects were covered by the glider only few days apart. C13W shows quite different behaviour from the other cyclone (C13E), above the ENACW. The salinity in C13W presents higher and more homogeneous values than in $\mathrm{C} 13 \mathrm{E}$, along the water column. 

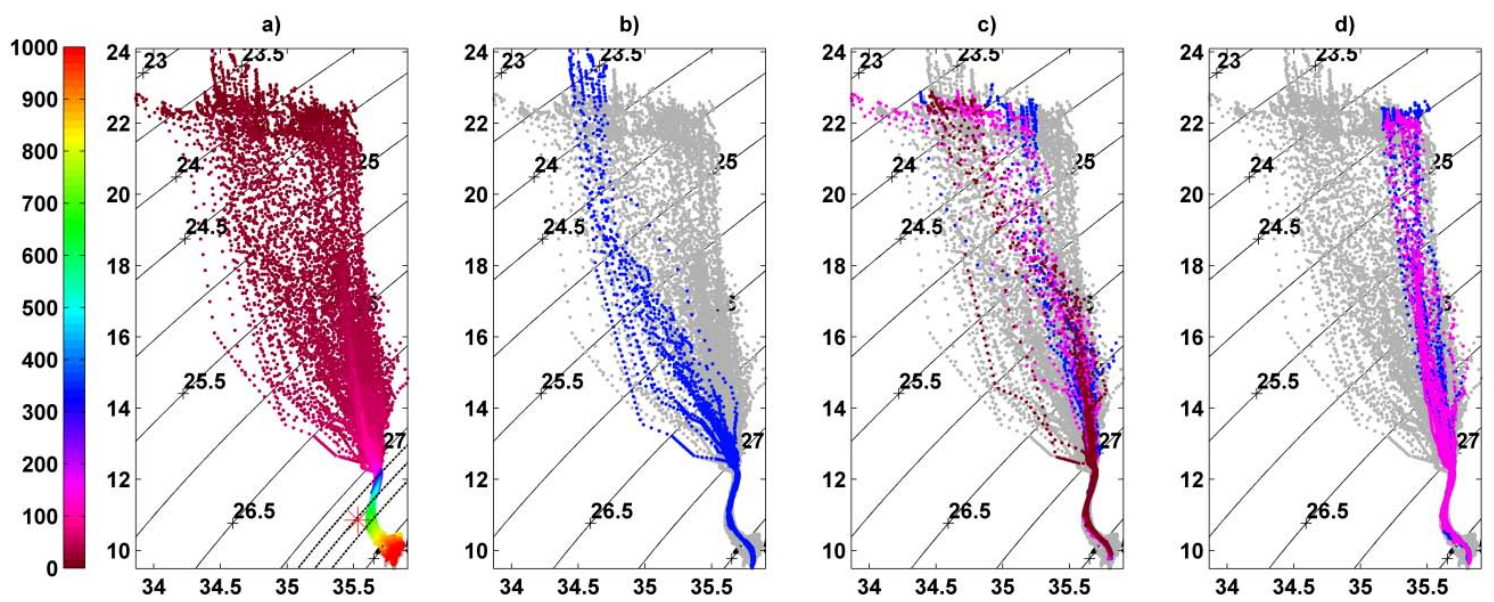

Figure 11. (a) $\Theta S$ diagram for all the glider profiles analysed. Colour represents the depth in $m$ of the $\Theta-S$ pairs. Asterisk gives the $\Theta-S$ values for the lowest layer of the NACW in the Cap Ferret area $\theta=10.85^{\circ} \mathrm{C}$, $S=35.53$, following Valencia et al. (2004). Dashed lines give the isopycnal lines 27.127 .2 and 27.3. From Somavilla et al. (2013), the core of ENACW is located in the Bay of Biscay at values of $\sigma_{\odot}$, between 27.1 and 27.2, and the bottom of ENACW (characterized by a salinity minimum layer) can be found between $\sigma_{\oplus}$ $=27.2-27.3$. $(b-d)$ grey points represent $\Theta-S$ pairs for all the glider profiles analysed, blue/pink/red points $\Theta-S$ pairs for profiles the first/second/third time the glider crossed the structures (b) C13E (c) X13 and (d) C13W.

A detailed analysis of $\Theta-S$ from surface to $100 \mathrm{~m}$ depth is presented in the following figures. As indicated before (Fig. 11a), there are some points that, despite showing $\Theta-S$ values similar to that of neighbouring points, are located at greater depths (Fig. 12a). In figure 12b, but mainly in 12c, it is showed that downwelling at these levels correspond to cyclones, which present deeper values (over $80 \mathrm{dbar}$ ) for water masses between 25.5 and 27 . In the case of the X13 anticyclone (Figs. 12d-f) this behaviour is not observed. Within X13 densities under 27 are observed at levels around $80 \mathrm{dbar}$ or shallower. In each of the passes through $\mathrm{X} 13$, the deepest $\Theta-S$ values do not vary significantly, as it does in the first $30-40 \mathrm{~m}$. The salinity in the first pass (Fig. 12d) was between 34.8 and 35.3; the salinity had a broader range during the second transect (Fig. 12e) in the surface (33.8 and 35.3). During the last pass, one can observe intermediate values with salinities ranging between 34.3-34.8. These differences in the surface salinity could be due to the sampling, the glider crossing different parts of the eddy at each pass. The centre is crossed during the first transect, whilst an area between the centre and the periphery is crossed during the other two passes. In addition, around $44^{\circ} 52^{\prime} \mathrm{N}-44^{\circ} 55^{\prime} \mathrm{N}$ fresh water $(<34.6)$ was measured from surface to 20 $\mathrm{m}$ depth. This fresh water could originate in the fresh water masses from river outflows (winter-spring) like those observed around mid-July 2009 west of the Landes Plateau to $4^{\circ} \mathrm{W}$ (Reverdin et al., 2013). 

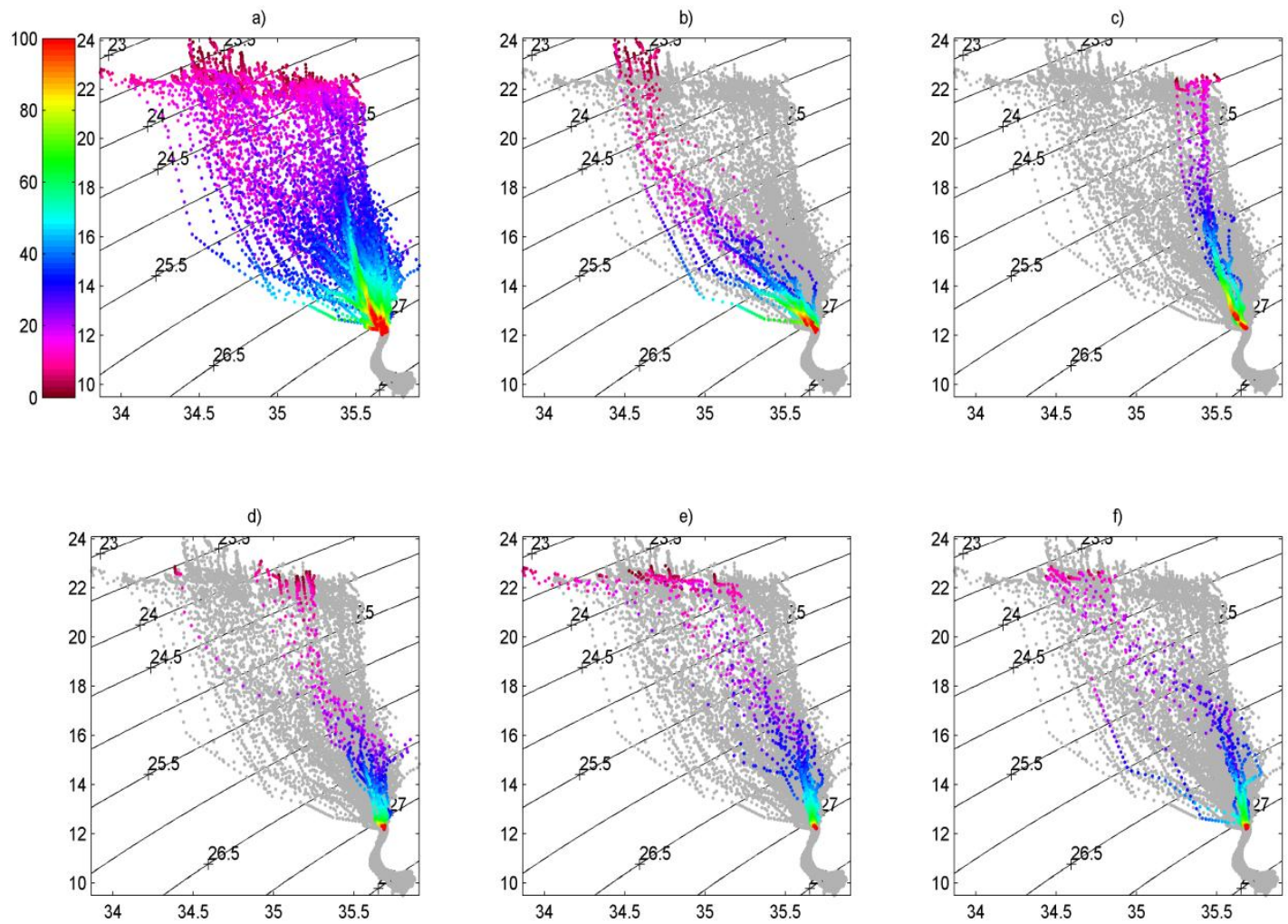

Figure 12. $\Theta-S$ diagrams for the glider profiles in the (a) whole domain (b) C13E eddy (c) C13W-1and the $(d-f)$ anticyclone from the three passes (X13-1, X13-2 and X13-3). Colour represents the depth in $m$ of the $\Theta-S$ pairs.

The seasonal thermocline was located at a mean depth of $30.3 \mathrm{~m}$, during the period and area of study (Table 2). The mean depth was shallower inside anticyclones (27.1 $\mathrm{m}$ ) and deeper inside cyclones $(32.4 \mathrm{~m})$. The difference was more remarkable, greater than $20 \mathrm{~m}$, when considering the maximum depth of the seasonal thermocline observed inside anticyclones $(35.6 \mathrm{~m})$ or cyclones $(57.4 \mathrm{~m})$. On the contrary, the mean depth of the isotherms near the permanent thermocline, i.e. the $11.5^{\circ} \mathrm{C}$ isotherm, was deeper $(457.9 \mathrm{~m})$ than the overall $(407.5 \mathrm{~m})$ depth, and also than inside cyclones $(360.6 \mathrm{~m})$; the maximum depth being near $100 \mathrm{~m}$ deeper (Table 2$)$.

Besides the hydrography, the Chl-a fluorescence significantly vary within eddies, both the depth of the maximum Chl-a fluorescence and the Chl-a fluorescence intensity (Table 2 and Fig. 13). The average Chl-a fluorescence inside anticyclonic eddies is higher than in the vertical profiles outside of eddies, and inside cyclonic eddies (Fig. 13, Left). In this figure, a maximum around $2.4 \mu^{-1}$ can also be observed, located around $50 \mathrm{~m}$ in the anticyclones. Depths of maximum Chl-a fluorescence are deeper within cyclones, where the mean maximum $\left(1.6 \mathrm{\mu g} \mathrm{I}^{-1}\right)$ is located at around $57 \mathrm{~m}$ depth. It is worthwhile to highlight the contribution of cyclones to the overall Chl-a fluorescence values between 60 and $120 \mathrm{~m}$. In relation to this, the previous study focused on SWODDY F90 (Garcia-Soto et al., 2002) also showed how the physical structure of the eddy perturbed the euphotic layer with increased levels of chlorophyll above the eddy centre, where the thermocline was domed upwards. The authors showed that the summer cyclones associated with the anticyclone had a depressed thermocline and reduced levels of chlorophyll. The histogram of the total Chl-a fluorescence (the sum of the Chl-a fluorescence over each vertical profile) inside anticyclones, cyclones and outside of these structures (Fig. 13, Right) reflects that in all the cases the maximum frequency is centred in $50 \mu \mathrm{g} \mathrm{I}^{-1}$. The profiles inside cyclones present the lower values of total Chl-a fluorescence with no data in the highest concentration $\left(\geq 80 \mu \mathrm{g} \mathrm{I}^{-1}\right)$; whilst 
the total Chl-a fluorescence of the profiles inside anticyclones shows the highest total values $\left(100 \mu \mathrm{g} \mathrm{I}^{-1}\right)$.

\begin{tabular}{|c|c|c|c|}
\hline & Global & Anticyclone & Cyclones \\
\hline Mean ( \pm std) depth of the seasonal ther & $30.3 \pm 6.9$ & $27.1 \pm 3.9$ & $32.4 \pm 9.3$ \\
\hline & encose & & 57. \\
\hline Mea & $407.5 \pm 42.8$ & $457.9 \pm 31.7$ & $360.6 \pm 33.4$ \\
\hline of the $11.5^{\circ} \mathrm{C}$ isotherm $(\mathrm{m})$ & & 527 & 423 \\
\hline Mean ( \pm std) depth of maximum Chl & $50.2 \pm 8.9$ & $49.7 \pm 6.3$ & $56.5 \pm 11.4$ \\
\hline Mean ( \pm std) of maximum Chl-a fluo & $1.9 \pm 0.8$ & $2.4 \pm 0.8$ & $1.6 \pm 0.6$ \\
\hline
\end{tabular}

Table 2. Mean and maximum depth of the seasonal thermocline and $11.5^{\circ} \mathrm{C}$ isotherm, mean depth of maximum Chl-a fluorescence and mean value of maximum Chl-a fluorescence for all the profiles and for those corresponding to the anticyclone and cyclones.
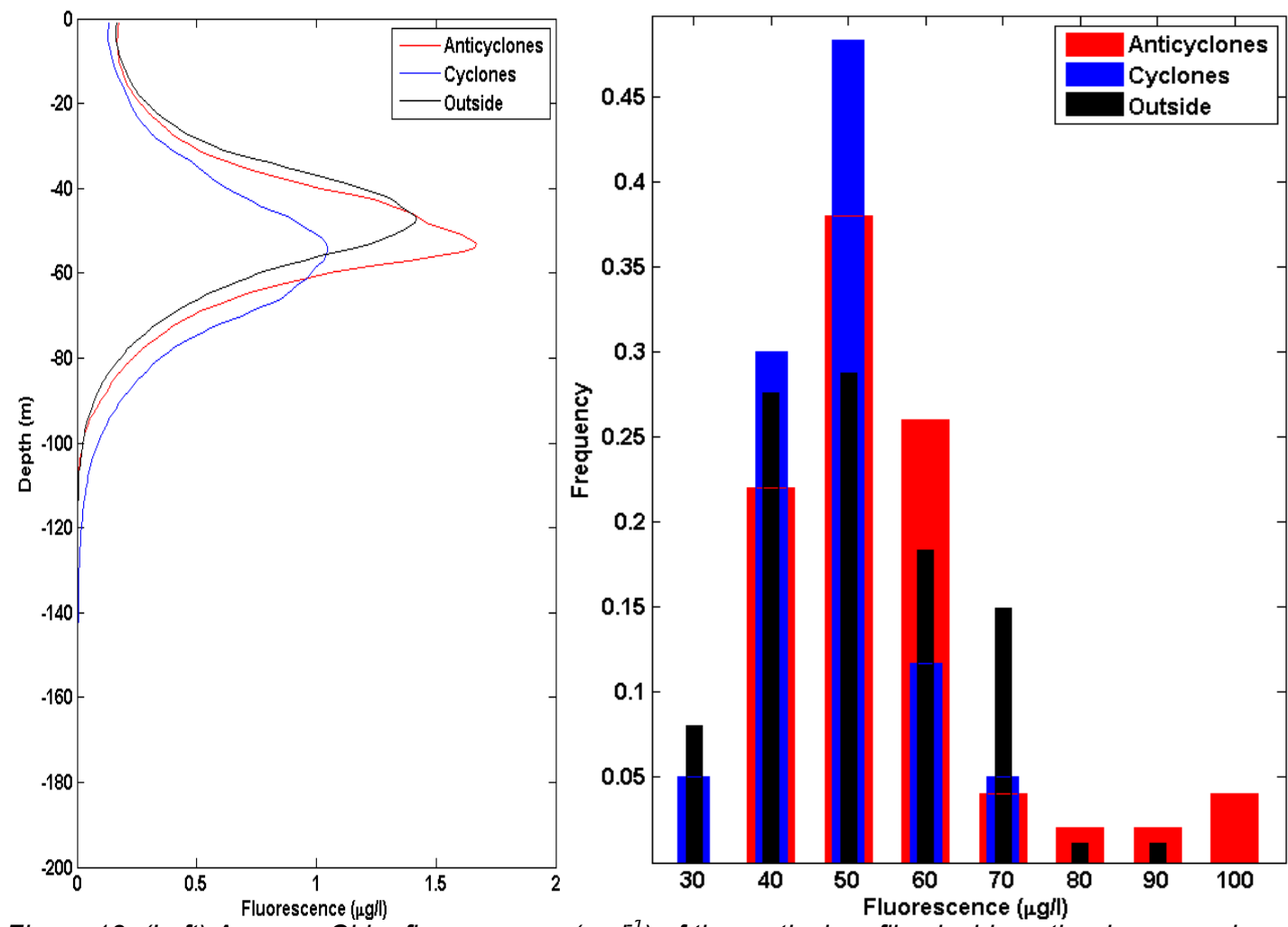

Figure 13: (Left) Average Chl-a fluorescence $\left(\mu g \Gamma^{-7}\right)$ of the vertical profiles inside anticyclones, cyclones and out of them, as a function of depth $(m)$. (Right) Histogram of the total Chl-a fluorescence ( $\left.\mu g \Gamma^{-1}\right)$ measured inside anticyclones, cyclones and in profiles outside of them.

\section{Summary and conclusions}

Glider and satellite data have been put together in this study for analysing the changes on the hydrography and $\mathrm{Chl}-\mathrm{a}$ fluorescence over the water column (from surface to $1000 \mathrm{~m}$ depth), induced by mesoscale eddy dynamics in the SE-BoB. First of all, a selection of the glider profiles corresponding to cyclonic or anticyclonic eddies has been done, based upon the vertical integrated currents and a COE detection method, as well as from the vertical position variations of a deep isotherm. This information has been supported also by satellite data.

Two cyclones (C13E and C13W) and an anticyclone (X13) have been identified. The altimetry maps detected the anticyclone, but not the cyclones. Past altimetry measurements have been reported for cyclones surrounding the SWODDY-like eddy AE6 (Garcia-Soto et al., 2002). In that case, the cyclones were located farther from the 
coast than $\mathrm{C} 13 \mathrm{E}$ and $\mathrm{C} 13 \mathrm{~W}$; therefore, it is probable that these last cyclones have not been identified due to their position close to the coast. The SST maps detected on the one hand X13 as a cold core structure with a sharp thermal front at its south and on the other hand the C13E also with a cold core (days before the beginning of the mission). With regard to $\mathrm{C} 13 \mathrm{~W}$, its periphery has been identified in Chl-a maps as a branch with higher Chl-a concentration on its periphery.

In terms of vertical properties, within $\mathrm{C} 13 \mathrm{E}$ and $\mathrm{C} 13 \mathrm{~W}$ the isotherms and isohalines are depressed from surface to at least $100 \mathrm{~m}$ depth; they rise from around $300 \mathrm{~m}$ to at least $750 \mathrm{~m}$ depth. They depress the depth of the seasonal thermocline but uplift the $11.5^{\circ} \mathrm{C}$ isotherm; showing two relative maximums of salinity on both sides of the COE inside the ENACW. The Chl-a fluorescence is higher under the thermocline, with the highest values found at the periphery of the core. With regard to X13, the opposite behaviour is observed on the vertical distribution of the isotherms, isohalines; as well as on the depth of the seasonal thermocline and of the $11.5^{\circ} \mathrm{C}$ isotherm. Centred on around 200 dbar there is a maximum of salinity (35.7) and temperature $\left(12.5^{\circ} \mathrm{C}\right)$. This type of core is typical of SWODDIES. The maximum Chl-a fluorescence is observed below the seasonal thermocline, in agreement with previous SWODDIES observations (SWODDY F90, Garcia-Soto et al., 2002) and in the COE.

The detailed analysis of cyclones and anticyclones profiles allows us to conclude that the $\Theta$-S distribution inside the first $100 \mathrm{~m}$ of the water column varies significantly from one structure to the other, even between cyclones. It can be observed from surface to $100 \mathrm{~m}$ depth how water masses inside cyclones (this is the contrary in the anticyclone) are located at higher depths than those corresponding to their $\Theta-S$ properties, suggesting that downwelling processes occur, or have occurred at these depths. The profiles of the different transects that crossed X13, show different $\Theta-S$ properties at shallower levels, which could indicate advective mixing processes with surrounding waters. Finally, the mean Chl-a fluorescence in the anticyclone core was higher than in the surrounding waters and its maximum was located at shallower waters. Cyclones presented conversely mean lower values, with the maximum located at deeper levels, in comparison with the anticyclone and the global mean. Both findings have been described before in the southern Bay of Biscay (Garcia-Soto et al., 2002). The variability of $\mathrm{Chl}-\mathrm{a}$ fluorescence in and outside the eddies suggests that these eddies, as other eddies located in the Bay of Biscay, have not only effect on the hydrography of the study area, but also a notable impact on the ecology. For this reason it is important to study in depth the eddies in the area, in order to know their peculiarities.

The vertical structure of the eddies, sampled during the GESEBB mission, provides evidence of eddy-wind interaction in the study area. In consequence, for this case, the common interpretation of the effect of the first baroclinic mode in eddies could not provide a complete understanding of the role of the observed structures in the environment. That is, for instance, assuming that anticyclones tend to downwell water masses and therefore they are not able to produce nutrient enrichment near the surface. Indeed, the observations from the GESEBB campaign show how eddy-wind induced Ekman pumping results in upwelling at the shallower levels of the anticyclone and allow us to observe a DCM around $40 \mathrm{~m}$ centred in X13 core. Within cyclones the opposite tendency is observed, with low Chl-a fluorescence in the core of the eddies and higher Chl-a fluorescence at their periphery.

Due to the lack of a dense 3D survey of cyclones, vertical dynamics of the cyclonic features has not been studied further. However, their vertical structure is similar to that described for cyclonic thinnies in the literature (McGillicuddy, 2015). The joint analysis for X13 quasi-geostrophic vertical velocities and eddy-wind induced Ekman pumping allows to conclude that the observed Chl-a fluorescence distribution could result from a 
combination of these two processes. Internal quasi-geostrophic dynamics will contribute to increase the Chl-a fluorescence intensity at the eddy's periphery while eddy-wind induced upwelling will contribute to the shallower Chl-a fluorescence maximum observed at its centre. In the cyclones, a similar behaviour at the periphery (due to internal dynamics) could be expected; whilst opposite behaviour in the surface layers (due to Ekman pumping) will not favour high Chl-a fluorescence values in the core. Finally, it is worth noting that the effect of Ekman pumping (always opposite to geostrophic balance) will induce lower geostrophic velocities at the surface levels of these eddies, thus it will have an impact in the retention of passive particles by these eddies (i.e. Phytoplankton or zooplankton). Further investigation of the effects of windeddy interaction on the retention capabilities of these structures in the Bay of Biscay, will be particularly interesting to deepen the understanding of their effects in the ecosystem. Indeed, from vertical sections of geostrophic velocities, the anticyclone maximum geostrophic velocities were located at shallower levels thus, indicating increased capabilities for retention in comparison to the cyclones. Higher concentration of Chl-a fluorescence and higher retention in anticyclones suggest that, in this case, anticyclones instead of cyclones would provide the most favourable conditions to increased primary productivity in the study area.

\section{Acknowledgements}

This study has been undertaken with the financial support of the Spanish Ministry of Economy and Competitiveness (National Plan for Scientific and Technical Research and Innovation, CTM2013-45423-R project), the Department of Environment, Regional Planning, Agriculture and Fisheries of the Basque Government (Marco Program), and partially under the framework of the French ENIGME project. The glider was provided and piloted by the INSU-CNRS with the support of the first call of the JERICO transnational access (7th Framework Programme, FP7). Support from the EGO COST Action ES0904 and the FP7 GROOM project (Grant agreement No. 284321) is acknowledged. The mission was carried out with the inestimable help of Laurent Beguery in piloting the glider and advising us in the design of the mission; and also of Ana Rietz from Sasemar for its help in the security and logistics of the sea mission. We would like to thanks Francesco Nencioli (http://www.com.univ$\mathrm{mrs}$.fr/ nencioli/home.php) for providing us with his Matlab script for detecting COE from currents. Altimeter products produced by SSALTO/DUACS and distributed by Aviso, with support from CNES (http://www.aviso.oceanobs.com/duacs/).

SST and Chl-a data produced and distributed by NERC Earth Observation Data Acquisition and Analysis Service (NEODAAS, http://www.neodaas.ac.uk/data). This is contribution number 740, of the Marine Research Division of AZTI-Tecnalia.

\section{References}

- Allen, J.T., Smeed, D.A., Nurser, A.J.G., Zhang, J.W., Rixen, M., 2001. Diagnosis of vertical velocities with the $Q G$ omega equation: an examination of the errors due to sampling strategy. Deep-Sea Res. 48, 315-346.

- Alvera-Azcarate A., Barth, A., Beckers, J.-M., 2008. Thermocline characterization on modeled and observed temperature profiles: a technique for model error evaluation. Geophys. Res. Abstracts, Vol. 10, EGU2008-A-03926. EGU General Assembly 2008.

- $\quad$ Aviso, 2014. SSALTO/DUACS User Handbook: (M)SLA and (M)ADT Near-Real Time and Delayed Time Products, CLS-DOS-NT-06-034 - Issue 4.1. 
- Caballero, A., Pascual, A., Dibarboure, G., Espino, M., 2008. Sea level and Eddy Kinetic Energy variability in the Bay of Biscay, inferred from satellite altimeter data. J. Mar. Syst. 72 (1-4), 116-134.

- Caballero, A., Ferrer, L., Rubio, A., Charria, G., Taylor, B. H., Grima, N., 2014. Monitoring of a quasi-stationary eddy in the Bay of Biscay by means of satellite, in-situ and model results. Deep Sea Res. Part II-Topical Studies in Oceanography, 509 doi: 10.1016/J.DSR2.2013.09.029.

- de Boyer Montégut, C., Madec, G., Fischer, A.S., Lazar, A., ludicone, D., 2004. Mixed layer depth over the global ocean: an examination of profile data and a profile-based climatology, J. Geophys. Res., 109, C12003. doi:10.1029/2004JC002378.

- $\quad$ Ducet, N., Le Traon, P.-Y., Reverdin, G., 2000. Global high-resolution mapping of ocean circulation from TOPEX/Poseidon and ERS-1 and -2. Journal of Geophysical Research 105, 19477-19498.

- Esnaola, G., Sáenz, J., Zorita, E., Fontán, A., Valencia, V., and Lazure, P.: Daily scale wintertime sea surface temperature and IPC-Navidad variability in the southern Bay of Biscay from 1981 to 2010, Ocean Sci., 9, 655-679, doi:10.5194/os-9-655-2013, 2013.

- Fernández, E., Álvarez, F., Anadón, R., Barquero, S., Bode, A., García, A., García-Soto, C., Gil, J., González, N., Iriarte, A., Mouriño, B., Rodríguez, F., Sánchez, R., Teira, E., Torres, S., Valdés, L., Varela, M., Varela, R., Zapata, M., 2004. The spatial distribution of plankton communities in a Slope Water anticyclonic Oceanic eDDY (SWODDY) in the southern Bay of Biscay. J. Mar. Biol. Assoc. U.K., 84: 501-517.

- Ferrer, L., Liria, P., Bolaños, R., Balseiro, C., Carracedo, P., González-Marco, D., González, M., Fontán, A., Mader, J., Hernández, C., 2010. Reliability of coupled meteorological and wave models to estimate wave energy resource in the Bay of Biscay. Proceedings of the 3rd International Conference on Ocean Energy (ICOE), 6-8 October 2010, Bilbao, Spain, 6 pp.

- Garau, B., Ruiz, S., Zhang, W., Pascual, A., Heslop, E., Kerfoot, J., Tintoré, J., 2011. Thermal Lag Correction on Slocum CTD Glider Data. J. Atmos. Oceanic Technol., 28, 1065-1071.

- Garcia-Soto, C., Pingree, R.D., Valdés, L., 2002. Navidad development in the southern Bay of Biscay: Climate change and SWODDY structure from remote sensing and in situ measurements. J. Geophys. Res. 107, 3118, doi: 10.1029/2001JC001012, 29 pp.

- Garcia-Soto, C., Pingree, R.D., 2012. Atlantic Multidecadal Oscillation (AMO) and Sea Surface Temperature in the Bay of Biscay and adjacent regions. J. Mar. Biol. Assoc. U.K., 92 (2): 213-234. DOI: 10.1017/S0025315410002134

- Gaube, P., McGillicuddy Jr., D.J., Chelton, D.B., Behrenfed, M.J. Strutton, P.G., 2014. Regional variations in the influence of mesoscale eddies on near-surface chlorophyll. Journal of Geophys. Res. Oceans, 119, doi:10.1002/2014JC010111.

- Gaube, P., Chelton, D.B., Samelson, R.M., Schlax, M.G., O’Neill, L.W., 2015. Satellite observations of mesoscale eddy-induced Ekman Pumping. J. Phys. Oceanogr, 45, 104-132.

- Gomis, D., Ruiz, S., Pedder, M., 2001. Diagnostic analysis of the 3D ageostrophic circulation from a multivariate spatial interpolation of CTD and ADCP data. Deep-Sea Res., 48, 269-295.

- Gomis, D., Pedder, M., 2005. Errors in dynamical fields inferred from oceanographic cruise data. Part I: The impact of observation errors and the sampling distribution. J. Mar. Syst., 56, 317-333. doi:10.1016/j.jmarsys.2005.02.002.

- GROOM group, 2014. D5.3 Report describing protocols for sampling, sample analysis, inter-calibration of missions, data analysis, EU FP7GROOM project 
Call FP7 Infrastructures 2011-2, grant agreement No. 284321, http://www.groom-fp7.eu/doku.php?id=public:deliverables

- Hoskins, B. J., Draghici, I., Davies, H. C., 1978. A new look at the omega equation. Quart. J. Roy. Meteor. Soc., 104, 31-38.

- Lavín, A., Valdés, L., Sanchez, F., Abaunza, P., Forest, A., Boucher, B., Lazure, P., Jegou, A. M., 2006. The Bay of Biscay: The encountering of the ocean and the shelf, in The Sea, vol. 14, chap. 24, pp. 933-1001, NOAA, Silver Spring, Md.

- Le Cann, B., Pingree, R., 1995. Circulation dans le Golfe de Gascogne: une revue de travaux récents. Actas del IV Coloquio Internacional sobre Oceanografia del Golfo de Vizcaya, Santander, Spain. pp. 217-223.

- Le Traon, P.-Y., Nadal, F., Ducet, N., 1998. An improved mapping method of multisatellite altimeter data. Journal of Atmospheric and Oceanic Technology 15, 522-534.

- McGillicuddy, D.J., Johnson, R., Siegel, D.A., Michaels, A.F., Bates, N.R., Knap, A.H., 1999. Mesoscale variations of biogeochemical properties in the Sargasso Sea. J. of Geophys. Res. 104(C6), 13,381-313,394.

- McGillicuddy Jr., D.J., Anderson, L.A., Bates, N.R. Bilbby, T., Buesseler, K.O., Carlson, C.A., Davis, C.S., Ewart, C., Falkowski, P.G., Goldthwait, S.A., Hansell, D.A., Jenkins, W.J., Johson, R., Kosnyrev, V.K., Ledwell, J.R., Li, Q.P., Siegel, D.A. Steinberg, D.K., 2007. Eddy/Wind interactions stimulate extraordinary Mid-Ocean plankton blooms. Science, 316, 1021-1026.

- McGillicuddy Jr., D.J., 2015. Formation of Intrathermocline Lenses by EddyWind Interaction. J. Phys. Oceanogr., 45, 606-612. doi: http://dx.doi.org/10.1175/JPO-D-14-0221.1

- Nencioli, F., Dickey, T.D., Kuwahara, V.S., Bidigare, R.R., Rii, Y.M., 2008. Physical dynamics and biological implications of a mesoscale eddy in the lee of Hawaii: cyclone Opal observations during E-Flux III. Deep-Sea Res. Part II, Vol 55, pp 1252-1274. doi:10.1016/j.dsr2.2008.02.003

- New, A.L., Pingree, R.D., 1990. Large-amplitude internal soliton packets in the central Bay of Biscay. Deep-Sea Res., 37A (3), 513-524.

- New, A.L., Pingree, R.D., 1992: Local generation of internal soliton packets in the central Bay of Biscay. Deep-Sea Res., 39A (9), 1521-1534.

- Pascual, A., Faugère, Y., Larnicol, G., Le Traon, P.-Y., 2006. Improved description of the ocean mesoscale variability by combining four satellite altimeters. Geophys. Res. Lett. 33, L02611, doi:10.1029/2005GL024633, 4 pp.

- $\quad$ Pingree, R.D., Mardell, G.T. New, A.L., 1986. Propagation of internal tides from the upper slopes of the Bay of Biscay. Nature, 321 (6066), 154-158

- Pingree, R.D., Le Cann, B., 1990. Structure, strength and seasonality of the slope currents in the Bay of Biscay region. J. Mar. Biol. Assoc. U.K., 70, 857885.

- Pingree, R.D., Le Cann, B., 1992a. Three anticyclonic Slope Water Oceanic eDDIES (SWODDIES) in the southern Bay of Biscay in 1990. Deep-Sea Res.39 (7/8), 1147-1175.

- Pingree, R.D., Le Cann, B., 1992b. Anticyclonic eddy X91 in the southern Bay of Biscay, May 1991 to February 1992. J. Geophys. Res. 97 (C9), 1435314367.

- Pingree, R.D., Garcia-Soto, C., 2014. Plankton blooms, ocean circulation and the European slope current in the Bay of Biscay (NE Atlantic): Response to Weather and Climate. Deep Sea Res. Part II, 106, 5-22.

- Pinot, J.M., Tintoré, J., Gomis, D., 1995. Multivariate analysis of the surface circulation in the Balearic Sea. Prog. Oceanogr., Vol. 36, Pergamon, 343-376.

- Pollard, R.T., Pu, S., 1985. Structure and circulation of the upper Atlantic Ocean northeast of the Azores, Prog. Oceanogr., 14(1-4), 443- 462. 
- Pollard, R.T., Griffiths, M.J., Cunningham, S.A., Read, J.F., Pérez, F.F., Ríos, A.F., 1996. Vivaldi 1991-A study of the formation, circulation and ventilation of eastern North Atlantic Central Water, Prog. Oceanogr., 37(2), 167- 192.

- Prieto, E., González-Pola, C., Lavín, A., Sánchez, R.F., Ruiz-Villarreal, M., 2013. Seasonality of intermediate waters hydrography west of the Iberian Peninsula from an $8 \mathrm{yr}$ semiannual time series of an oceanographic section, Ocean Sci., 9, 411-429, doi:10.5194/os-9-411-2013.

- Puillat, I., Lazure, P., Jégou, A.-M., Lampert, L., Miller, P.I., 2004. Hydrographic variability on the French continental shelf in the Bay of Biscay, during the 1990s. Cont. Shelf Res. 25, 1143-1163.

- Reverdin, G., Marié, L., Lazure, P., d'Ovidio, F., Boutin, J., Testor, P., Martin, N., Lourenco, A., Gaillard, F., Lavin, A., Somavilla, R., Mader, J., Rubio, A., Blouch, P., Rolland, J., Bozec, Y., Charria, G., Dumas, F., Louazel, S., Chanut, J., 2013. Freshwater from the Bay of Biscay shelves in 2009. Journal of Marine Systems, 109/110, 134-143.

- Rodríguez, F., Varela, M., Fernández, E., Zapata, M., 2003. Phytoplankton and pigment distributions in an anticyclonic slope water oceanic eddy (SWODDY) in the southern Bay of Biscay. Marine biology, 14, 995-1011.

- Rubio, A., Fontán, A., Lazure, P., González, M., Valencia, V., Ferrer, L., Mader, J., Hernández, C., 2013. Seasonal to tidal variability of currents and temperature in waters of the continental slope, SE Bay of Biscay. J. Mar. Syst. 109-110, S121-S133.

- Ruiz, S., Pelegrí, J. L., Emelianov, M., Pascual, A., Mason, E., 2014. Geostrophic and ageostrophic circulation of a shallow anticyclonic eddy off Cape Bojador. J. Geophys. Res.: Oceans, 119(2), 1257-1270.

- Sánchez, R., Gil, J., 2004. 3D structure, mesoscale interactions and potential vorticity conservation in a SWODDY in the Bay of Biscay. J. Mar. Syst., 46, 4768.

- Skamarock, W.C., Klemp, J.B., Dudhia, J., Gill, D.O., Barker, D.M., Wang, W., Powers, J.G., 2005: A Description of the Advanced Research WRF Version 2. NCAR Technical note NCAR/TN-468+STR.

- Solabarrieta, L., Rubio, A., Castanedo, S., Medina, R., Charria, G., Fernández, V., Hernández, C., 2014. Surface water circulation patterns in the south-eastern Bay of Biscay: new evidences from HF radar data. Continental Shelf Research, $74,60-76$

- Somavilla, R., González-Pola, C., Rodríguez, C., Josey, S.A., Sánchez, R.F., Lavín, A., 2009. Large changes in the hydrographic structure of the Bay of Biscay after the extreme mixing of winter 2005, J. Geophys. Res., 114, C01001, doi: 10.1029/2008JC004974.

- Somavilla, R., González-Pola, C., Ruiz-Villarreal, M., Lavín, A., 2011. Mixed layer depth (MLD) variability in the southern Bay of Biscay. Deepening of winter MLDs concurrent with generalized upper water warming trends? Ocean Dynamics 61 (9), 1215-1235. doi:10.1007/s10236-011-0407-6.

- Testor P., Meyers G., Pattiaratchi C., Bachmayer R., Hayes D., Pouliquen S., Petit de la Villeon L., Carval T., Ganachaud A., Gourdeau L., Mortier L., Claustre H., Taillandier V., Lherminier P., Terre T., Visbeck M., Krahman G., Karstensen J., Alvarez A., Rixen M., Poulain P.M., Osterhus S., Tintore J., Ruiz S., Garau B., Smeed D., Griffiths G., Merckelbach L., Sherwin T., Schmid C., Barth J.A., Schofield O., Glenn S., Kohut J., Perry M.J., Eriksen C., Send U., Davis R., Rudnick D., Sherman J., Jones C., Webb D., Lee C., Owens B., Fratantoni D., 2010: Gliders as a component of future observing systems, in Proceedings of OceanObs09: Sustained Ocean Observations and Information for Society (Vol. 2), Venice, Italy, 21-25 September 2009, Hall J., Harrison D.E., and Stammer D., Eds., ESA Publication WPP-306, Vol. II, pp1021-1038, doi:10.5270/OceanObs09.cwp.89. 
- van Aken, H. M., 2000. The hydrography of the mid-latitude Northeast Atlantic Ocean. II: The intermediate water masses, Deep Sea Res. Part I, 47(5), 789824, doi: 10.1016/S0967-0637(99)00112-0.

- Valencia, V., Franco, J., Borja, A., Fontán, A., 2004. Hydrography of the SouthEastern Bay of Biscay. In: Borja, A., Collins, M. (Eds.), Oceanography and Marine Environment of the Basque Country. Elsevier, pp. 159-194 (chap. 7). 